\title{
NATURE READERS.
}

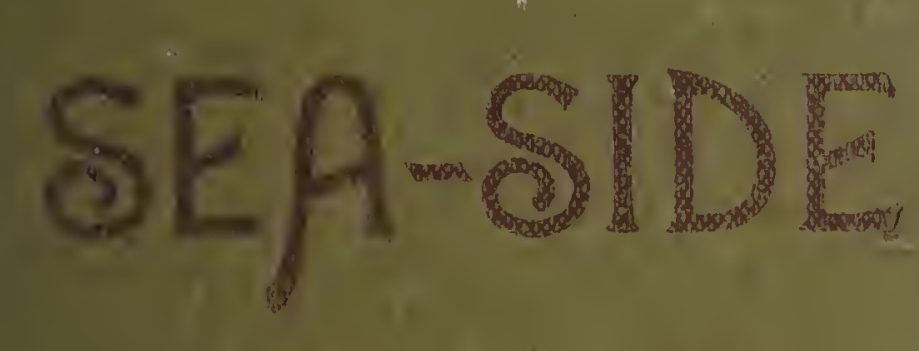

AND

(a)

gis
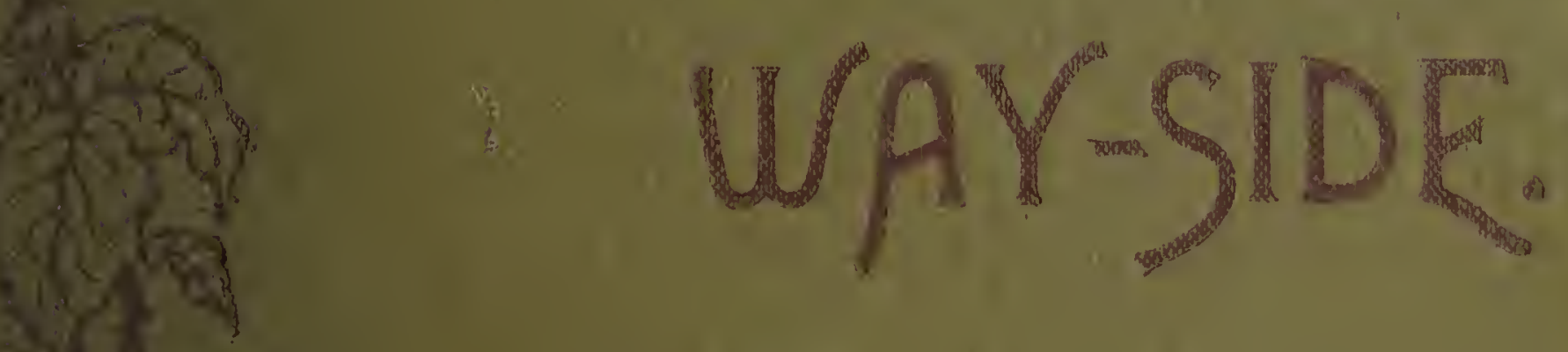

$-\mathrm{NO}_{2} \mathrm{H}_{0} \ldots$
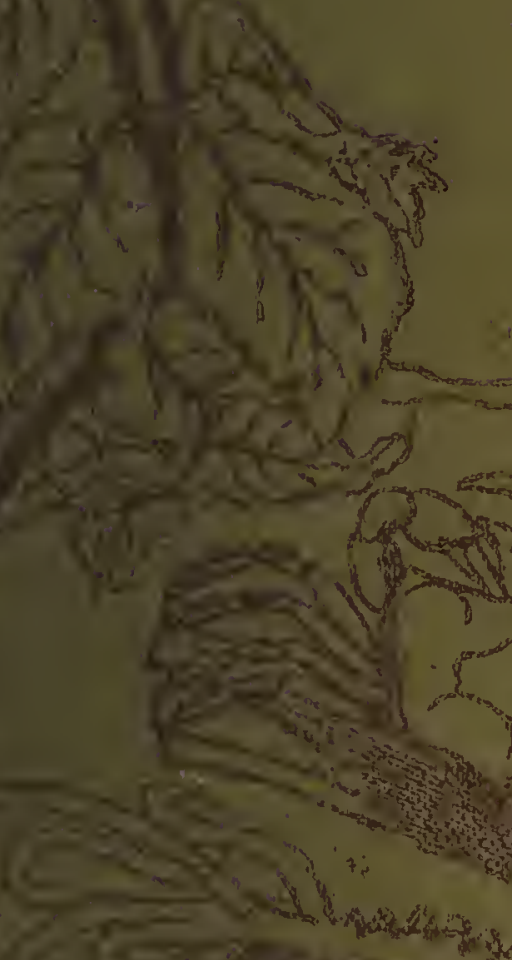

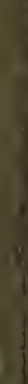

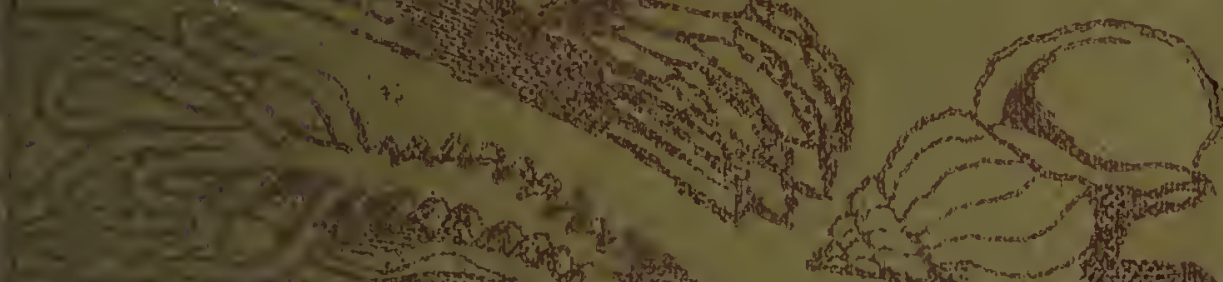

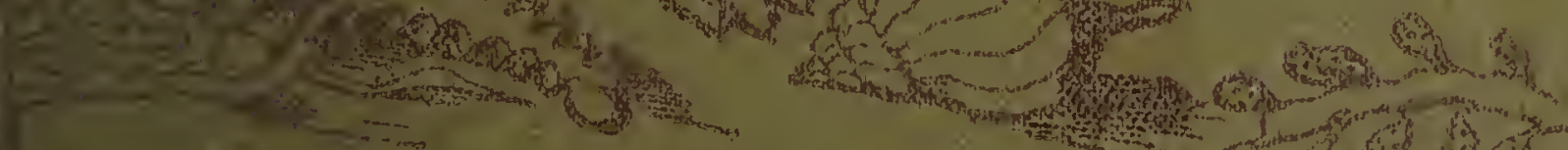

Pas $x$

.

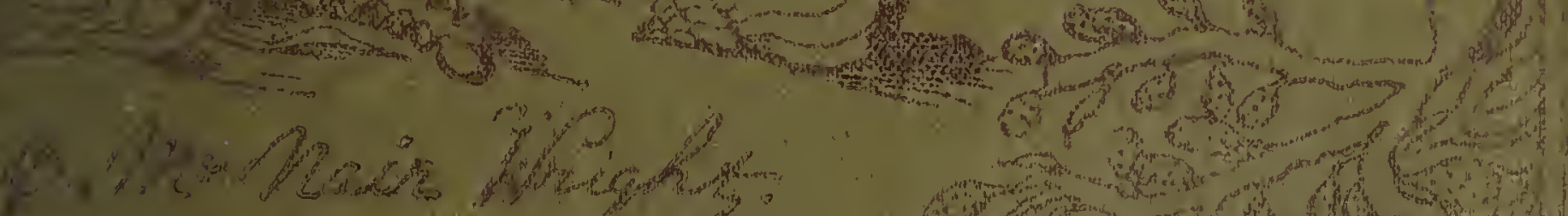
and $\Rightarrow x^{4}$

211- (180 (15) 


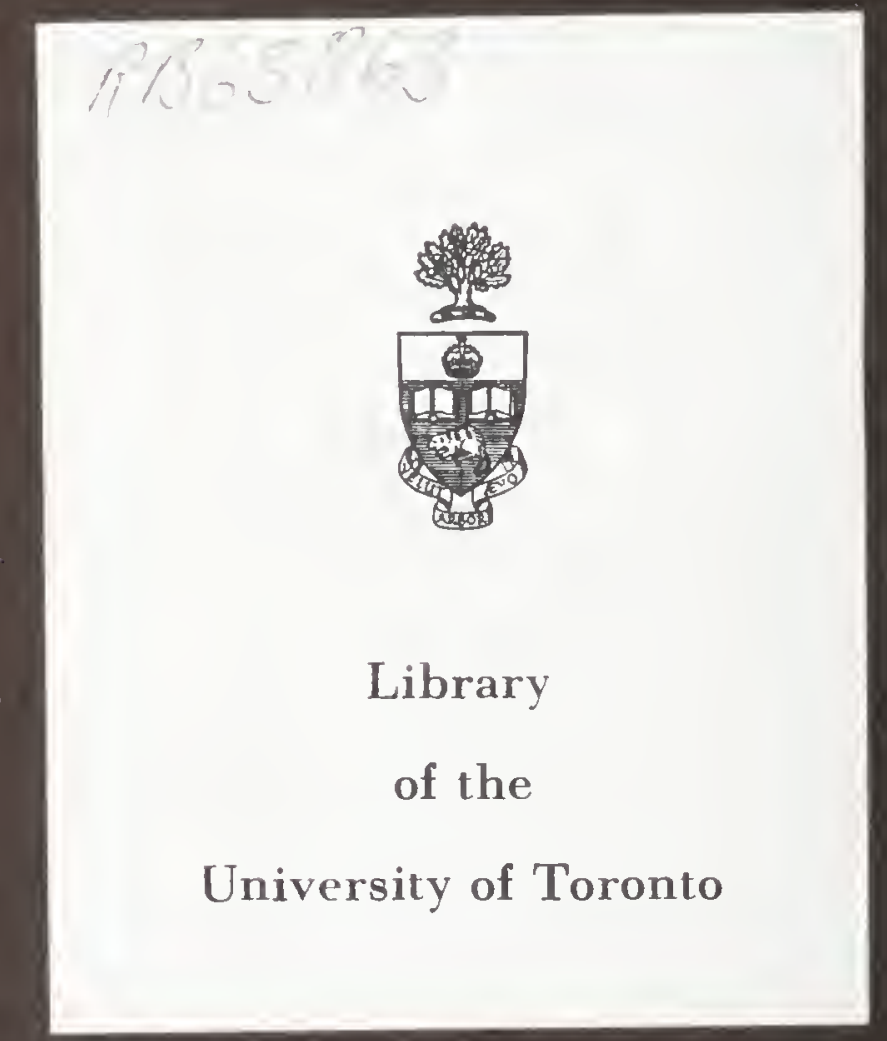





$$
\begin{aligned}
& -1+1=4.4 . \\
& \text { pras }
\end{aligned}
$$




\section{Digitized by the Internet Archive in 2018 with funding from University of Toronto}




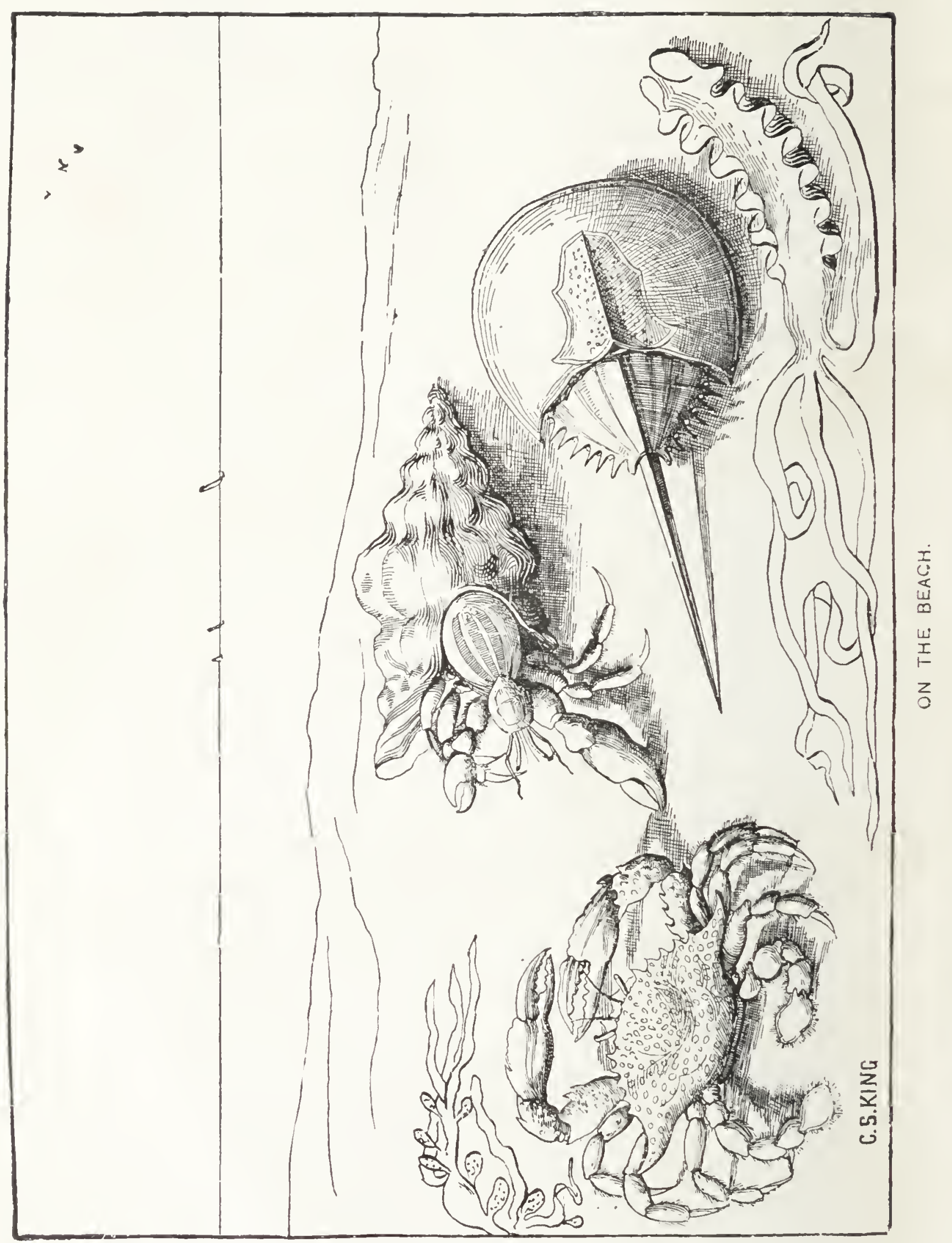




\section{Mature TReaders.}

\section{SEA-SIDE AND WAY'SIDE。}

\section{No. 1.}

BY

\section{JULIA MCNAIR WRIGHT.}

¿Then Nature, the old nurse, took

'The child upon her knee,

Saying, 'Here is a story-book

Thy Father hath written for thee.'"

LongFellow to Agassiz.

THE EDUCATIONAL SUPPIX ASSOCIATION,

(LIMI'l'ED,)

42 A HOLBORN VIADUCT, LONDON. 



\section{PREFACF.}

This Series of Nature Readers is intended for the use of beginners in reading. 'The subjects chosen, and their treatment, have been alike subordinated to this object. The Nature Readers are not offered as text-books in natural science, but rather as a contribution to the idea that facts of real and permanent value, may be made known, a noble taste nay be cultivated, thought may be developed, and the initiatory-steps in an increasingly popular study may be taken, while a child is learning to read a certain number of English words.

Should not the first short, strong Saxon sentences be rather used to convey scientific facts, than such trivial information as, "The boy has a new hat," or, "I had a plate of green peas to eat"?

Lessons fresh from the sea-shore and the field, where life is seen, not in an abnormal state, as captivity, but in its own chosen homes and natural development, cannot fail to have an educative power of great value, even to minds of a very early age.

The ieal difficulty to be overcome has been to put these simple lessons concerning the habits, homes, and anatomy of certain animals, into such words as are usually found in the most elementary reading-books. To accomplish this, so that the series shall reach the hands for which it was intended, has been the author's chief concern. There is happily no uncertainty as to the scientific accuracy of the work. Every substantive statement has been 
verified by the observation of the author, or of those whose competency for such work is unquestioned. 'The practical value of this series of Nature Readers must now be tried in the Homes and the Schools.

Whether the pages have been discreetly broken into paragraphs to catch restless and maccustomed eyes, whether the words and subjects have been fitly chosen, whether the individuality and personality given to irrational animals shall succeed in attracting the interest, and fixing the wandering thought of childhood, are all questions rather to be answered by a trial of the book, than argued in a preface.

We bring no cat and dog stories, no tales of monkey antics; but we have endeavored to impress upon the little Heir of life, in one of its highest forms, a comprehension of, and a reverence fol', life, even in some of its lower manifestations.

'This object has already been kindly commended, and generously welcomed, by no small number of skilled teachers and scientists, who have given valuable time to the reading of manuscript and proof of this series.

To those parents and teacher's who will give the books a careful trial, and reinforce these simple instructions by their own enthusiasm and experience, the Nature Readers are commended by

THE AUTHOR. 


\section{TO THE BOYS AND GIRLS.}

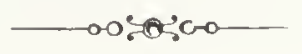

Do you know that there are cities on your path to school, and under the trees in your garden? Do you know that homes with many rooms in them hang in the branches above your head? Do you know that what you call "insects" hunt and fish, make paper, saw wood, are masons and weavers, and feed and guard and teach their little ones, much as your papa and mamma take care of you? This sounds like a fairy story, but it is a true fairy story.

In this book you will read of some of these wonders. And when you have read this book well, you shall have one or two more.

These books will not try to tell you all that there is to tell of these things. They are only to wake up your minds, so that you will think and study and notice these things for yourselves.

Your eyes will be worth many times as much to you as they now are, when you learn to observe with care and to think about what you see. 



\section{CONTENTS。}

LESSON

I. Mr. And Mrs. Crab • 。 。 。 。 1

II. Mr. Crab and his House . 。 。 。 3

III. More about Mr. Crab. . . • • . 5

IV. Mr. and Mrs. Crab get a New Coat. • o 7

V. What the Crab does • • • • 。 9

VI. Mr. Crab and ilis Friends . • 。 。 . 12

VII. Some Other Crabs . . . 。. . 。 14

VIII. 'The Hermit Crab . … ^. 。 。 . 17

IX. 'The Crab's Enemies . . . o c 。 20

X. Tine Uses of Crabs . . 。 。 22

XI. Mrs. Wasp and her Hone. 。 。 24

XII. What Mrs. Wasp Can do . 。 。 。 26

XIII. A Look at Mis. WASP 。 。 28

XIV. Mrs. Wasp's Yliak . 。 。 。 。 . 29

XV. Mrs. Wasp at Hone • 。 。 。 31

XVI. Review . . . . 。 。 。 33

XVII. The Bee and tile Man 。 。

XVIII. How the BeE is made. 。 。 . 36

XIX. 'The Bee at Hone 。 。 。 。 。 38

XX. 'The BeE Babies. 。 。 。 40

XXI. 'The Bee War 。 。 。 。 42

XXII. Tine Ber's Work。 。 。 。 44

XXIII. The Wise Bees . o 。 o. 。 45 
viii CONTENTS.

LESSON

XXIV. Earti Bees . 。

XXV. Other Bees . . . 。 。 49

XXVI. More about Bees . . . 。 . . 51

XXVII. The Spider and his Dress • • • . 52

XXVIII. 'The SpIder AT Hone . . . 。 . 55

XXIX. The Little Nest . . . . • . 58

XXX. The Spider and his Food 。 。 60

XXXI. Very Queer Spiders . . • . . 62

XXXII. Review . . . . . . 65

XXXIII. Out of Harm's Way . . . . . 67

XXXIV. Shell-Fisil . . . . . . 69

XXXV. 'The Story of Mr. Conchi . . . 。73

XXXVI. SEA-BABIES . . . . . . 75

XXXVII. More about SEa-Babies . . . 77

XXXViII. About Mr. Drill, . 。 。 。 79

XXXiX. The Stony of a WAR . 。 。 81

XL. How Shell-Fisit Feed . 。 。

XLI. REVIEW • 。 。 。 。 。 86 


\section{SEA-SIDE AND WAY-SIDE.}

-

LESSON I.

MR. AND MRS. CRAB.

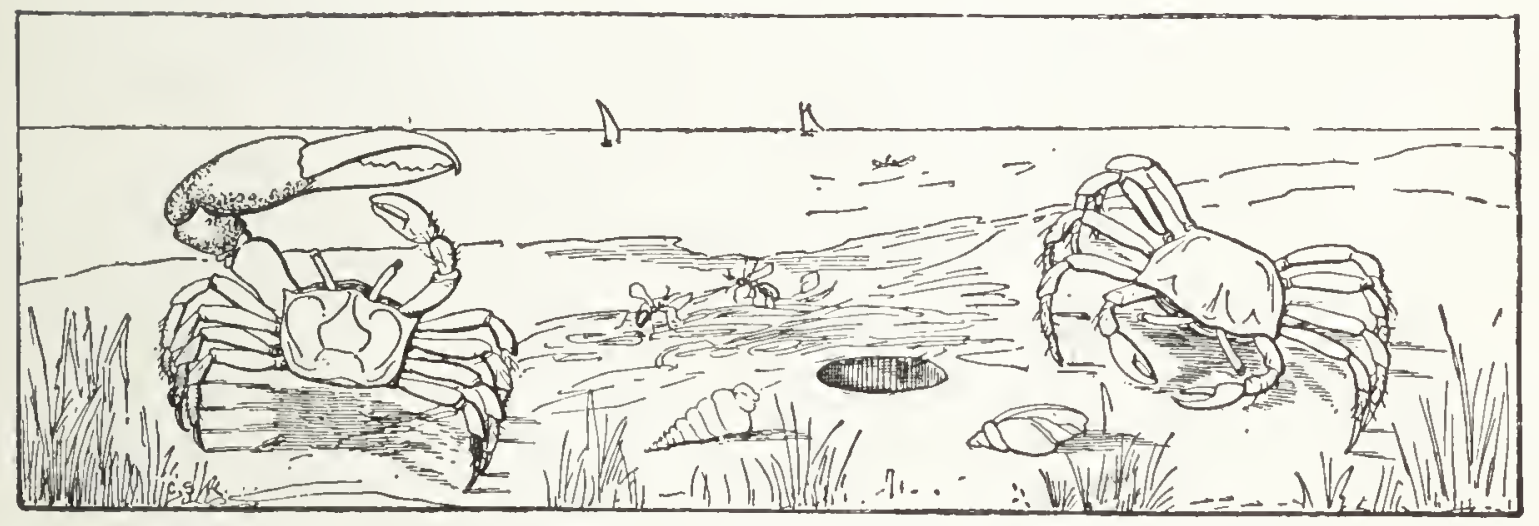

MR. AND MRS. CRAB.

This is a picture of Mr. and Mrs. Crab.

Do you see the round hole?

It is the door of their house.

Mr. Crab lives in the sand by the sea-side.

He has a smooth, flat shell on his back.

The crab has eight legs and two hands.

One hand is large; the other hand is small.

He fights with the big hand, and takes his food with the little hand, or with both hands. 
Mr. Crab digs out his house in the sand; he makes a place for a hall, a bed-room, and a pantry.

Mrs. Crab does not dig.

Both her hands are small and weak.

She gets food to put into the pantry.

She never fights.

If she is in any trouble she runs home, or to a hole in a rock.

See what queer eyes!

They are set on pegs; some call them stalks.

The crab can push the eye-pegs out and pull them in. Would you not look odd if you could make your eyes stand out six inches?

When crabs go into their houses, they draw down their eyes and tuck in their feet.

Crabs are of many colours.

They are red, brown, green, yellow, and blue. The claws are often of a very bright colour.

The colour on the shell is less bright; it is in small dots.

The colour on some kinds of crabs is in lines. No crab is clear, bright red when it is alive. When it is boiled it takes a fine red hue. Why is this?

We cannot tell why the heat makes it change colour. 


\section{ESSON II.}

MR. CRAB AND HIS HOUSE.

The water of the sea comes and goes in tides.

Twice each day the water rises - then it is high tide. After each high tide the water goes back - then it is cbb tide.

Each tide lasts six hours.

When the snow melts in the spring, or when much rain falls, the water rises high in the brook.

In the dry, hot days the water is low in the bed of the stream.

If the stream or brook were full and low twice each day, the change would be like the high and low tides of the sea.

When the tide is low, Mr. Crab digs out his house. He scoops out the sand with his big claw.

Then he folds his claw to carry the sand, as you can carry grass or leaves on your arm.

Some kinds of crabs carry the sand in three of their feet, bent to form a basket.

Mr. Crab takes the sand to the top of his hole. Then, with a jerk, he throws the sand in a heap. The crab is very strong.

He can lift and carry things larger than his body. 
He digs out a long hall.

He makes rooms in his house.

Then he goes with his wife to look for food.

They keep near their home.

They eat flies, gnats, ants, lady-birds, and other little insects.

They also eat sea-weed.

When beach-flies light on the sand or on sea-weed,

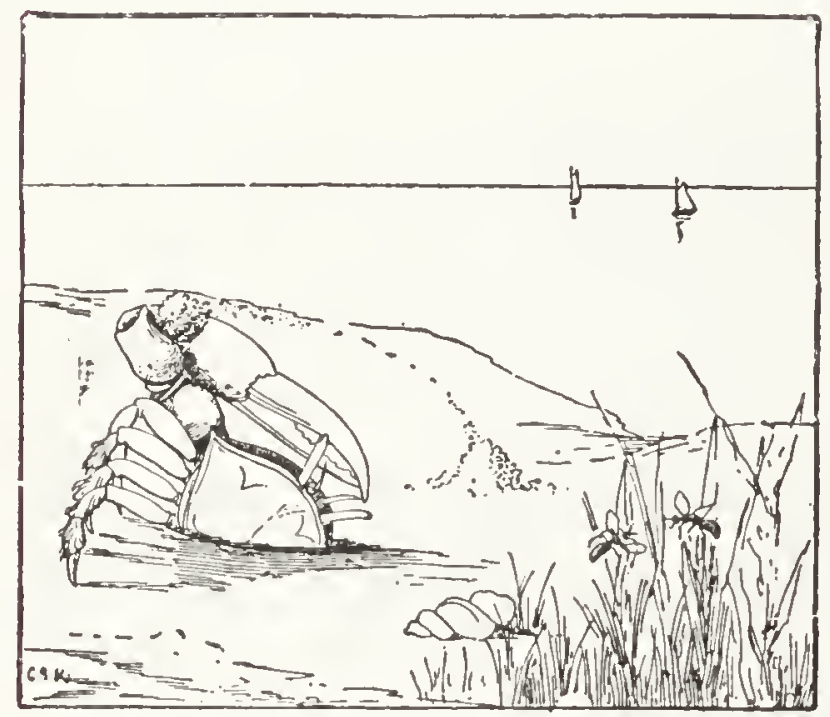

MR. CRAB MAKES HIS HOUSE. the crabs jump at them, and catch them as cats catch mice.

But the cats do not move so quickly as the crabs.

Mr. and Mrs. Crab put all that they catch into their pantry.

For six hours, while the tide is high, they stay in their house; and while they stay in the house they eat insects and seaweed they have stored away.

The crab acts as if he knew about the tide.

He knows when it will be high over his house.

He knows when it will be low, so that he can come out. 


\section{LESSON III.}

\section{MORE ABOUT MR. CRAB.}

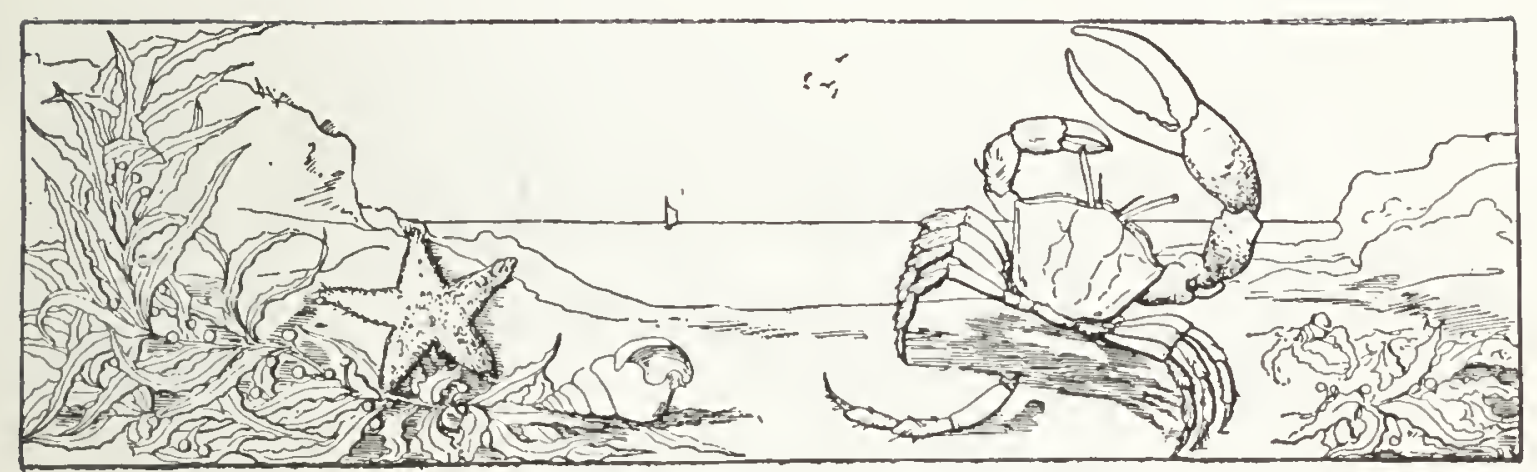

MR. CRAB RUNS AWAY.

I could, for a year, tell you queer things about Mr.

Crab.

Where are your bones?

They are inside your body.

Your bones are a frame to hold up your soft flesh.

Mr. Crab's bones are on the outside of his body.

His bones are his armour, to keep him from being hurt. The crab can live and breathe either in water or on land.

You can live only on land.

He can both walk and swim.

Mrs. Crab lays eggs.

A hen, you know, lays eggs, one by one, in a nest. She keeps them warm till the chicks come out. 
The crab's eggs are put in a long tube or sack. Mrs. Crab does not leave them in a nest.

She sarries them tied on her long legs, or, under her body.

When the small crabs come out of the eggs, they grow very fast.

When you catch a crab by his arm or leg, if you do not let go, he drops off this arm or leg, and rums. He will first pinch you, if he can, with his big claw. Could you run with one leg gone?

The crab has legs to spare.

Then, too, his legs will grow again.

Yours would not.

A crab's leg, or hand, will grow again very soon, when one has been lost.

But if his eye-peg is cut off, it takes a whole year for a new eye to grow.

I think he knows that; he is very careful of his eyes. The eye-pegs of one kind of crab are very long. He has a wide, flat shell.

There is a notch in each side of his shell. He can let his eyes lie in that notch. ${ }^{1}$

How can he do that? His eye-pegs are so long he can bend them down flat to the shell and keep them safe in the notch.

1 See Picture in Lesson IX. 


\section{LESSON IV.}

MR. AND MRS. CRAB GET A NEW COAT.

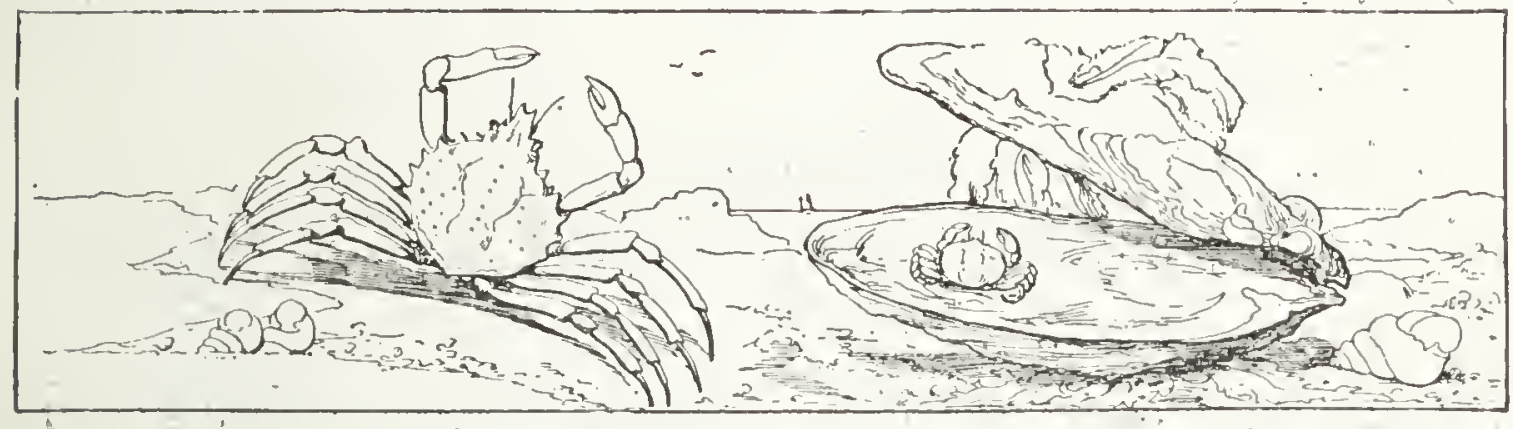

SPIDER CRAB AND LITTLE PINNA.

Your skin is soft and fine.

As you grow more and more, your skin does not break. Your skin gets larger as your body grows.

But Mr. Crab is in a hard shell.

The shell will not stretch.

It gets too tight, and what can Mr. Crab do then?

What do you do when your coat is too small?

Now I will tell you a strange thing.

When Mr. Crab finds that his shell is too small, he takes it off; as you take off your coat.

He pulls his legs, his hands, and his back, out of his shell.

He does that in his house.

You do not undress out of doors.

You go to your room. 
So does Mr. Crab.

He slips out of his shell.

He pulls out his feet and hands, as if he took off his boots and his gloves.

Then he is a poor, soft, cold thing.

But over all his body is spread a skin, soft as paste, like glue and lime.

In a few days it gets hard.

It is as big as Mr. Crab, and just fits his shape.

It is a good, new shell!

It has the right colours, - blue, brown, red, or gold.

It has spots and rings.

When Mrs. Crab changes her shell, Mr. Crab stays near, and tries to keep her from being hurt.

The young crabs have to change their shells often, they grow so fast.

Crabs that live in dark mud have dark brown or green shells.

Some crabs have sand-coloured shells, ${ }^{1}$ - pale gray or brown shells, with close, fine specks like sand on them.

There are more kinds of crabs than you could count. They live in all parts of the world.

This book tells you of only a few of them. 


\section{LESSON V.}

\section{WHAT THE CRAB DOES.}

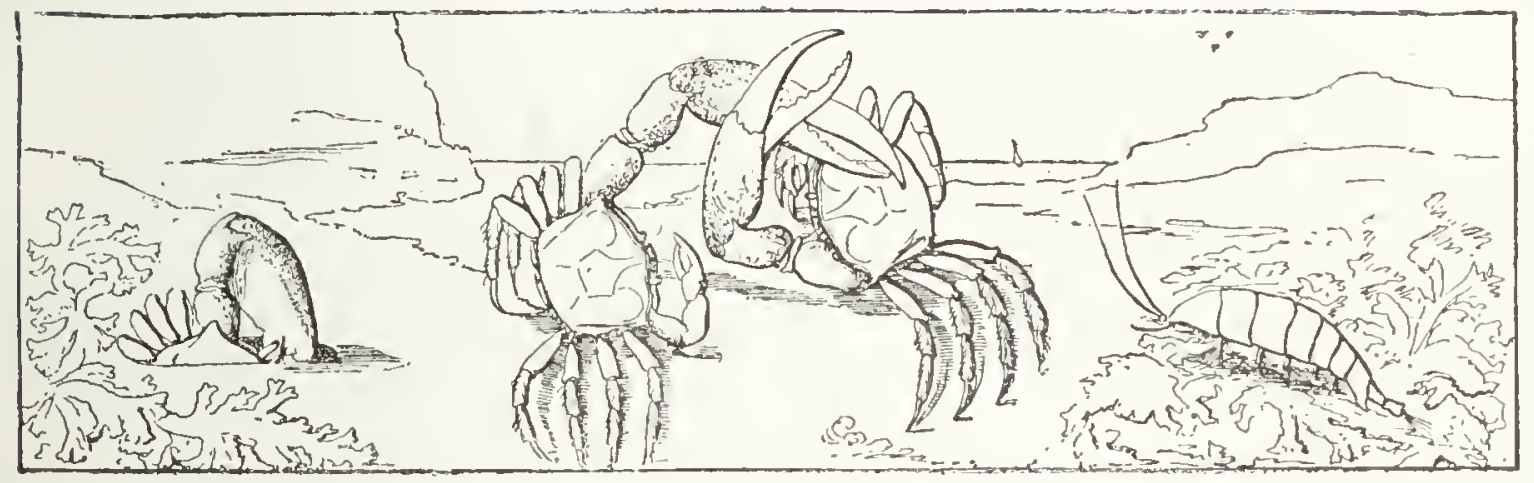

FREE FIGHT.

The crab is quick to get cross.

Are you?

He likes to fight.

In that he is like a bad boy.

When he sees some other crab near his house, he is angry.

Then he stands high on his toes.

He pulls in his eye-pegs, for fear they will be hurt.

He spreads out his big arin.

Now he is ready to fight!

He runs at his enemy!

Each tries to hit the other with his big claw.

This big claw, or hand, can cut and pinch hard. 
Sometimes one crab cuts off the hand or leg of the other crab.

Or he bites the shell on his back.

If only a leg is cut off, the crab may keep on fighting. But if his hand, or eye, or back shell is hurt, he must give up.

He runs home to hide, until a new eye, or hand, or leg can grow.

If your hand is cut off, will it grow again?

When a crab is afraid, he runs home.

But he is very brave, and does not much fear other crabs.

He fears birds most; for birds eat small crabs; and the crab cannot fight a big bird.

Swing a rag over a crab's head.

Up fly his eye-pegs!

Up comes his big hand!

There, he has caught the rag!

He will not let go.

You can lift him into the air by the rag; still he holds on.

Once I saw a blue crab catch a dog's tail.

The crab held on fast.

The dog howled, and ran up and down the beach. We had to catch the dog, and pull open the crab's claw. Let us look at this crab; he has let go the rag, and has gone to dig in his house. 
Lay this bit of shell on his hole.

See it shake!

He has run up and hit it with his head.

Now he waits.

Watch well.

There, the shell flies up in the air!

He struck it hard as he ran, and made it fly up.

I have seen him try twice, and make the shell shake,

before he fourd how hard he must hit, to get

it wit of the way.

Some folks think he shuts the door of his house with his big hand.

I do not think so.

He knows that the tide will wash a lump of sand over his hole, for a door.

The tide shuts him in.

He watches the waves come near.

At the last wave he flies into his door, for he knows the next wave will close it.

He never stays up one wave too long. He gets in in time.

He is shut in his house with Mrs. Crab.

He knows that the tide will pass soon.

When Mr. Crab has lost a leg or hand, and a new one grows, it is small at first.

Then when he gets a new coat, the new hand or leg becomes half as large as the one he lost. 
The next new coat, the new hand or leg comes out the full size it should be.

When cralss get new shells, we say they cast their old ones.

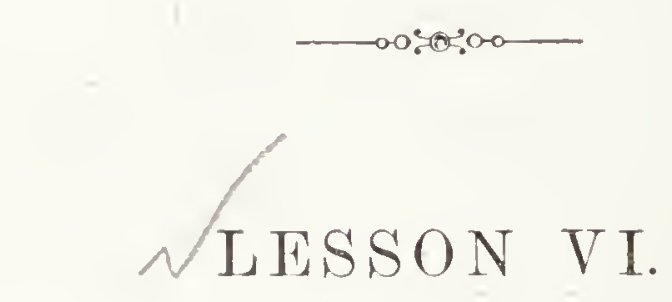

MR. CRAB AND HIS FRIENDS.

Tue crab that has one large claw has many names. Some call him the Fighting Crab, he is so cross.

Others name him the Calling Crab, because, when he runs, he holds his big claw high, as if he called, "Come! come!"

Most people call him the Fiddler Crab, and say that his big claw is his fiddle.

I think that is the best name for him.

He can, and does, play a tune on that hand.

It is his violin, as well as his hand, his spade, and his sword.

Do you see a row of little knobs on the inner edge of his big claw?

He rubs those knobs on the edge of the shell that covers his back, and the sound is his tune.

He uses that tune to call his mate.

Mrs. Crab thinks it fine. 
Mr. Crab has friends upon the beach, as well as down deep in the sand and in the water.

When he walks along the sand, he meets big flies with two wings.

He is glad to see them. Why?

They put their grubs, or young ones, in the sand, and Mr. Crab knows that he can find them to eat.

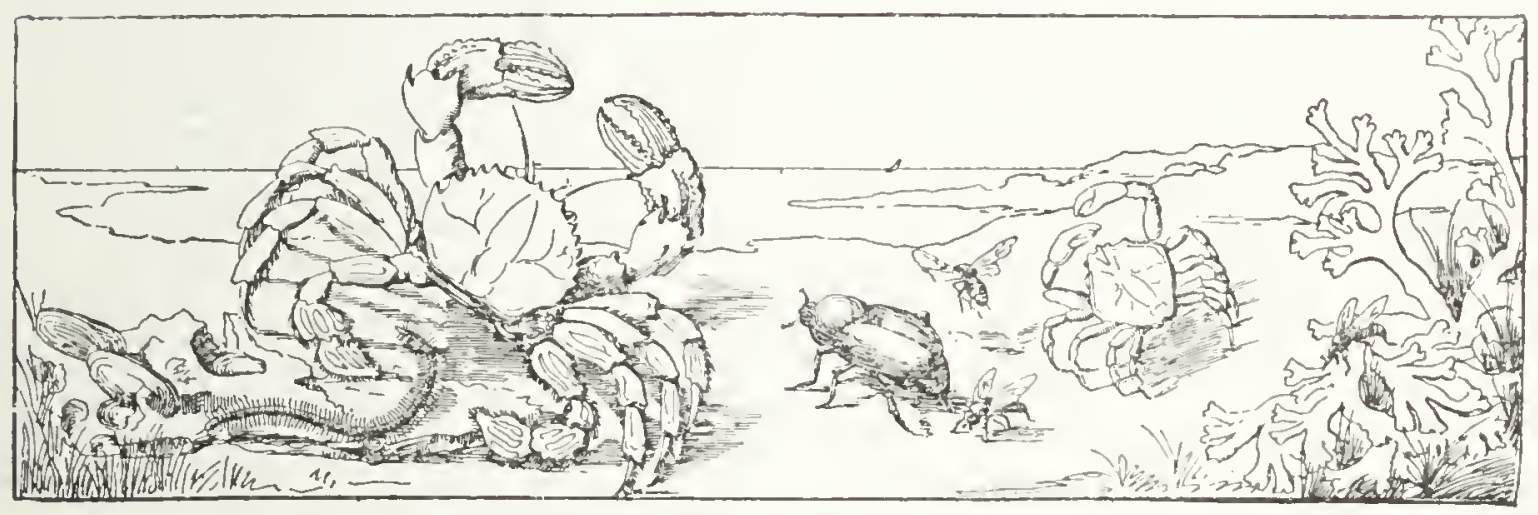

MR. CRAB AND HIS FRIENDS.

Mr. Crab also meets a great, green tiger beetle. He does not fight lim.

He knows that he shall find the beetle's grubs in the sand and eat them.

While he is digging down below, he meets a little fat, round crab, with big eyes, and a thin, graily shell. He is glad to see him.

If the crab has not food enough to eat while the tide is high, he will creep along in the sand, and catch and kill this small crab for his dinner.

Mr. Crab also meets, deep down, long worms, green, red, or brown. 
They are making houses for themselves.

He does not trouble them.

Out in the sea, Mr. Crab finds some small shell-fish called limpets.

He likes them so much that he lets them live on his shell.

They take fast hold on his back, and he does not pull them off.

\section{$-\infty .05000$ \\ LESSON VII.}

\section{SOME OTHER CRABS. ${ }^{1}$}

ALL crabs are not alike.

There are many kinds.

They differ in shape, colour, and habits.

Some are not at all pretty.

Some are very pretty.

All are very queer.

The Spider Crab ${ }^{2}$ has long, thin legs.

The front of his shell, which is over his head, is not wide, but is a sharp point.

This is to help him dig his way into sand and mud. Some crabs do not make a house in the sand; they live in holes in the rocks.

The Horse-Shoe Crab is of a chestnut colour.

1 See Frontispiece.

2 See Picture in Lesson IV. 
Some call him the King Crab.

Look at his picture. ${ }^{1}$

His shell is of the shape of the hoof of a horse, but it has a long tail, with sharp points on the edges.

The tail is as hard as wood, and has edges like a file. The Horse-Shoe Crab lives in sand and in mud.

He chooses the muddy banks where rivers or streams run into the sea.

He pushes his way in the mud, with his big, round shell, and scrapes the mud out with his many feet.

He eats the worms he finds in the sand and mud.

Why are the worms down there?

Like Mr. Crab, they build a house in the mud.

Some time I will tell you about these worms.

Now and then, as Mr. Crab goes along under the ground, he finds in his way a long, soft thing that looks good to eat.

It is the long pipe or tube with which a $\operatorname{clam}^{2}$ takes his food.

The King Crab puts out his claw to get it.

The King Crab can move his hand claw as quickly as your cat can jump or strike out her paw.

But the clam is far more quick than the King Crab, and shuts his shell down on the King Crab's claw.

Now is he held fast, like a rat in a trap!

He waits to see if the clam will let go.

1 See Frontispiece.

$2 \mathrm{~A}$ clam is a shell-fish found in tropical seas. 
No, he will not.

Then the crab drops off his claw, and goes away to hide and grow a new one.

Do you see, in the picture, a crab in a shell made like a curl ? ${ }^{1}$

That crab steals his house.

He finds an empty shell, and goes into it to live.

It is odd to see him run, with the shell he stole on his back.

How does he live?

By fishing.

All crabs homt and fish.

I have told you how they hunt on the sand for flies and insects.

Did I not tell you how they hunt for grubs and worms under ground?

How do they fish?

Mir. Crab gets into a good place to fish.

He pops out his eyes to see all about him.

Then when things that he likes to eat float by, he strikes out with his big hand.

He catches what he wants nearly every time. Crabs are very greedy.

3 See Frontispiece. 


\section{NLESSON VIII.}

\section{THE HERMIT CRAB.}

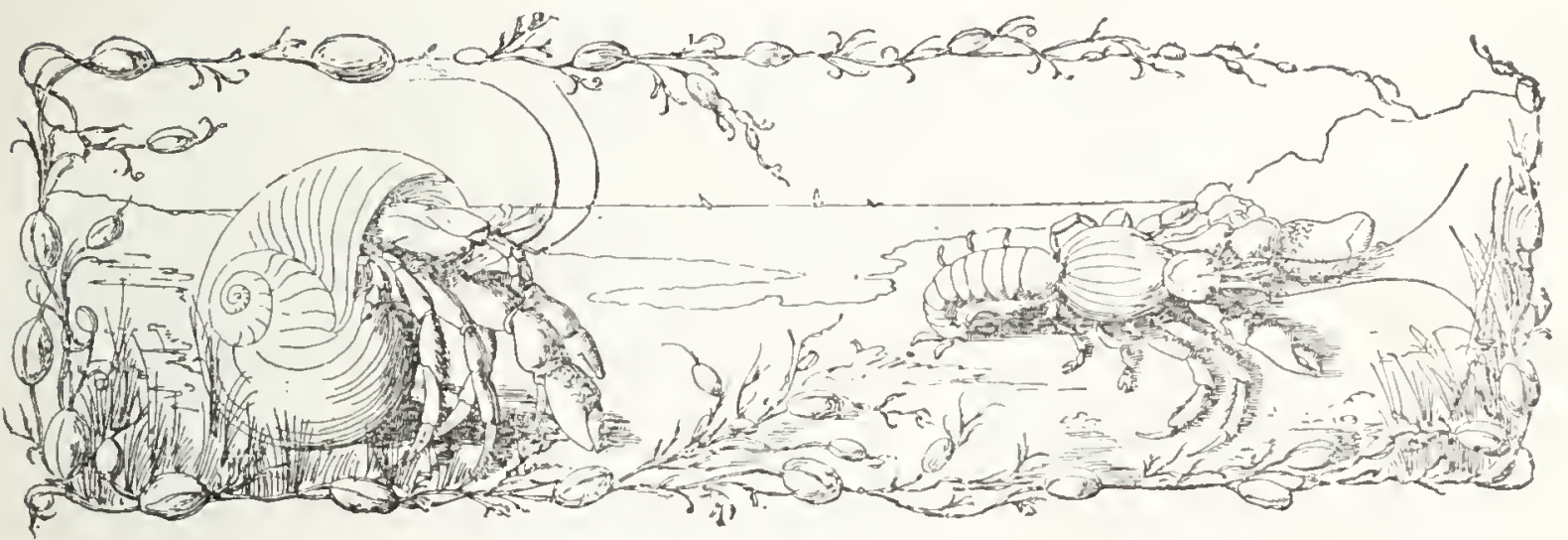

HE COMES OUT TO DIE.

Do you wish to hear more about the crab that steals his house?

Why does he do that?

His back is long and soft, and has no hard shell.

If he could find no hard cover, he could not live.

All the other crabs would bite or pinch him.

So would many fish.

He is called the Hermit Crab.

As the Hermit Crab grows too big for one shell, he finds another.

He never stays outside of his shell until he knows that he is about to die.

How does he know that?

I cannot tell. 
But he comes out, lies flat down by his house, and dies. He wants his house to live in, not to die in.

When he needs to change his shell-house, he hunts for one to suit him.

Then he puts in his long claw, to feel if it is clean and empty.

Now and then he finds another crab in it.

Then the two fight for it.

If some small thing lives in the shell which the hermit wants, he pulls it out with his long claw.

Then he brings the new shell near, and springs from the shell he is in to the shell he wants, as you would spring from chair to chair.

On the end of his long, soft tail he has a hook.

He twists his soft body into the new shell.

Then he clasps his tail-hook to a small, round post in the top of the curl of the shell.

That holds him fast.

His horny legs hang out in front.

He can rum and carry the shell.

He can draw back into the shell and hide.

Theie is a small, pink, sea-animal, like a flower, that one crab loves.

He wants it to grow on his shell.

It may be that it helps him to catch food.

Or, it may be that he likes it to hide the door of his shell. 
This pink sea-creature can build more shell on the edge of the one the crab lives in.

This makes the shell larger.

Then the crab need not move so often.

When he moves, he takes his friend with him.

He puts out his claw and lifts her off his old shell, and sets her on the edge of the new one.

Then he holds her there until she has made herself fast.

Then he slips in, tail first.

The fine red, pink, and white frills of the friend hang like a veil over his door.

They keep fish and other foes away.

For this pink thing can sting.

Once I found a nice shell.

I thought it was empty, and I kept it for eight or ten days in a box.

Then I laid it on a shelf.

One day I heard, clack! clack! clack!

And there was my shell running up and down the shelf!

A Hermit Crab had been in it all that time.

How did he live so long without food or drink? 


\section{LESSON IX.}

THE CRAB'S ENEMIES.

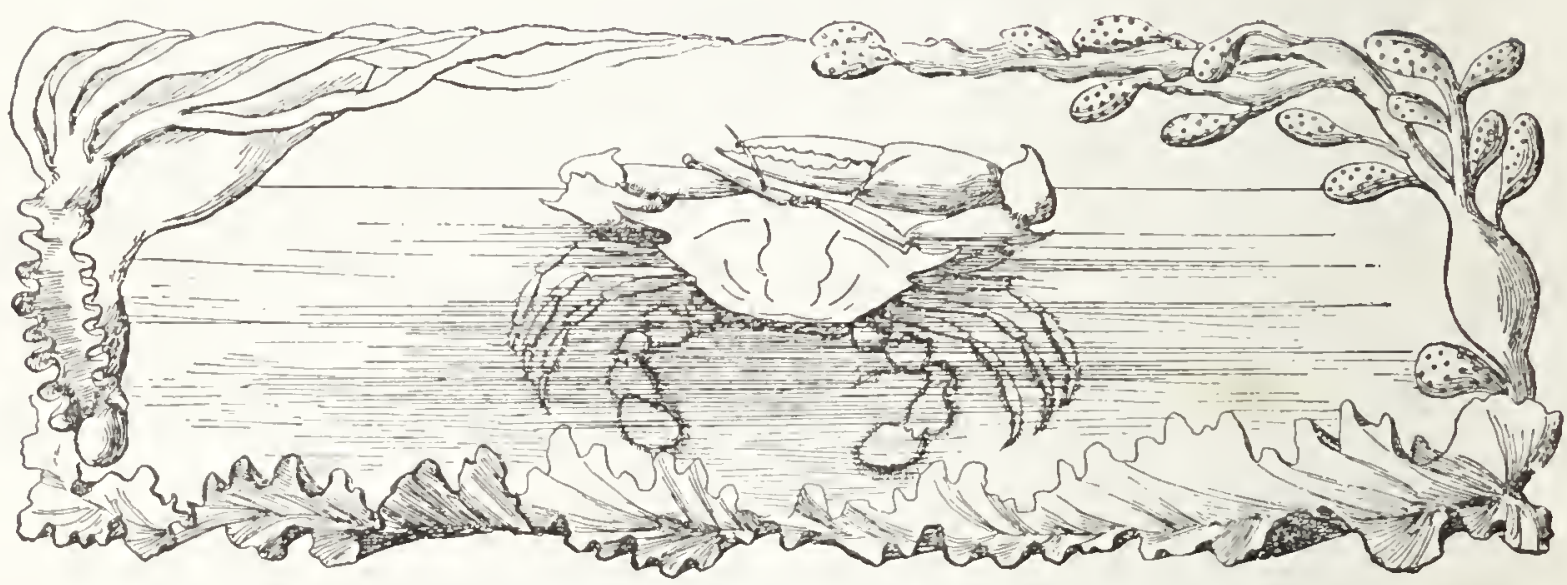

HIS HOME IS ON THE SEA.

Crabs have many enemies. Fish and birds eat them. Men eat some kinds of crabs. Crabs eat each other. With so many enemies, crabs would soon be all gone, if they did not lay so many eggrs. Mrs. Crab, each year, lays more eggs than you could count. Crabs do not always have hard shells.

When they first come from the egg they have long tails, four legs, and no claws. The crab's body then has a thin cover. He can swim well.

A little pink crab, named Pea Crab, goes to live in the shell of the oyster. The oyster does not seem to mind it.

You may see this little crab in your oyster soup. He 
turns orange colonr when he is cooked. Pimna, or Pea Crab has a very soft shell.

The Spider Crab has a brown shell, rough like sand. It has little thorns all over it.

This Spider Crab cuts off fine sea-weed with her little sharp claws, and hangs it like ribbons on these thorns or hooks. ${ }^{1}$

Then she looks like a little green grove! Who san tell why she does that? Is it to hide?

Do you see the wide hind feet of the crab in this picture?

Those are his padiles, or oars. They are his swimming feet.

His shell is wide and light. He can float on the waves like a boat. He goes far out on the sea.

Some crabs can dig into the sand very fast.

They go in backwards. They slip out of sight like a flash.

Or, they leave the tips of their heads and their eyepegs out, to look about. Sand-crabs do this.

Their shells are a pale brown or sand colour. Their shells are wide and round behind, and come to a point in the front.

Their heads are in the narrow part of the shell. Their shells are rough.

They are swift runners. 
Some hide in holes in the rocks. Some are sand-colour, and their colour protects them.

When they are afraid, they lie flat on the sand, and it is hard to see them. Some birds have long, thin bills, with which to pick Mr. Crab out of his sand house.

\section{LESSON X.}

\section{THE USES OF CRABS.}

How often does Mr. Crab get a new coat? His coat does not wear out.

But it gets too small. Then he changes it to get a larger one.

The baby grows fast. You seem to see it grow.

You grow fast. They say it is hard to keep you in clothes.

You cannot wear the coat you had last year. But your papa can wear his coat for many years.

He will tell you that he is done growing.

It is so with a crab.

When he is very young, he grows fast. He needs a new shell very often.

When he is older, he grows more slowly. Then he gets a new coat every spring. 
At last he does not grow any more. He keeps the same shell, year after year.

It gets very hard and thick, and loses its bright color.

Very often it is nearly covered with limpets. They fasten their flat or pointed shells to the crab's back, and stay there. I cannot tell you just how long a crab lives.

Of what use is a crab? Have all things a use?

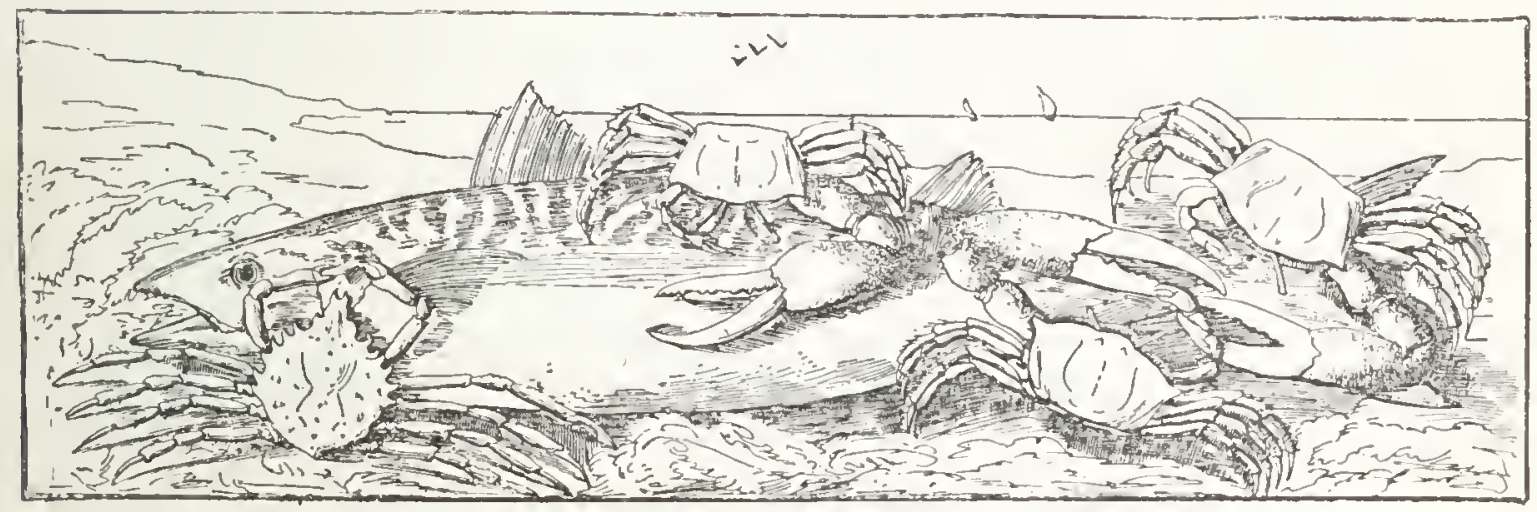

MR. CRAB HAS A PICNIC.

Yes. God made all things; and all things are of use. Sometimes we cannot find out the use. Crabs are good for food.

Some kinds are eaten by men, as fish and oysters are eaten. Then, too, birds eat a great many crabs. Some birds almost live on them. Fish eat many crabs. There are many kinds of crabs so small that you could hardly see them. Fish feed on them. And men catch and eat the fish. Then, too, crabs help to keep the sea and the sea-shore clean. 
Crabs are greedy. They eat nearly all kinds of dead things that would spoil and make a bad smell if left on the sand.

They eat dead fish, dead animals that are thrown into the sea, and grubs, flies, and worms. Do you ever see men groing about to clean the streets?

The crabs help to keep clean the sea and the shore. There are so many crabs, and they eat so much, and so fast, that they can clean away much of the dead stuff that lies on the shore.

\section{IESSON XI.}

MRS. WASP AND HER HOME.

Here is a round hole on the hill-side path. Is it a crab's hole?

No, it is too far from the sea for a crab. Mrs. Wasp made it for her baby to live in.

Her name is Vespa. In her house she has a hall, a room, and a bed.

In the bed her baby lies asleep. It, is now a soft, white egg.

When the baby wasp comes out of the egg, he will be all alone. When Mrs. Wasp has laid the egg safe in bed, she goes away. 
She shuts her door with a lump of mud. She leaves her baby some food to eat.

The food is a pile of little caterpillars. When she leaves her baby, she never comes back.

When he gets big, he digs his way out, and off he flies. If he meets his mother he does not know her. Mrs. Wasp makes her bed of fine sawaiust. She cuts the wood up soft and fine.

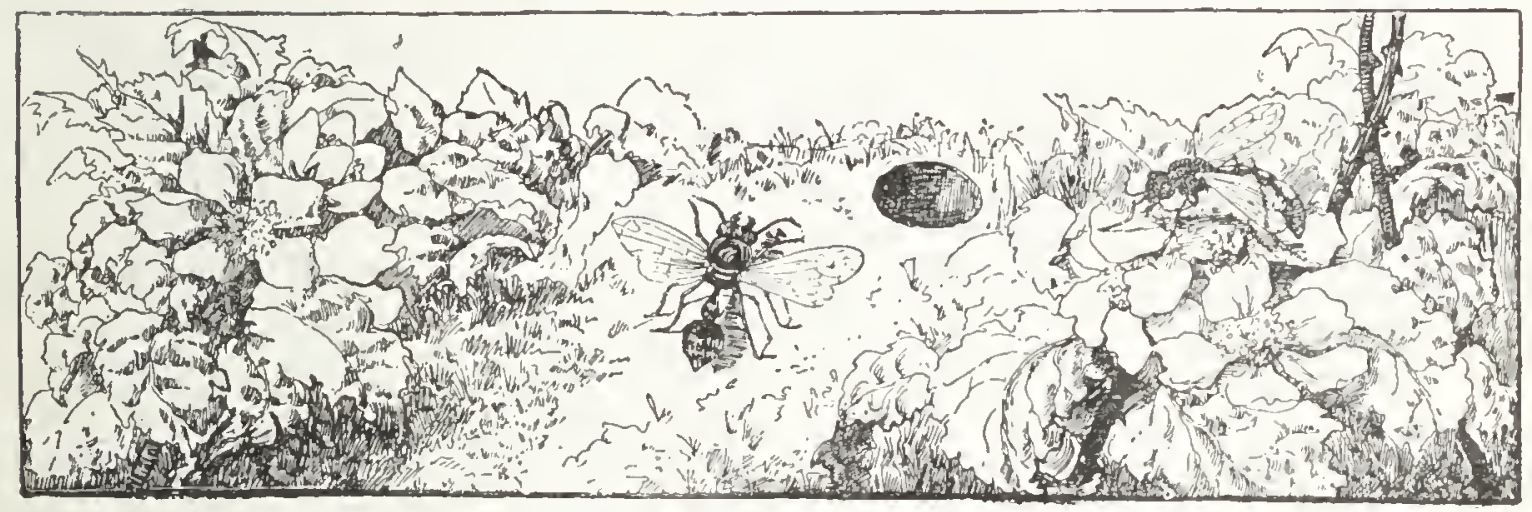

A WAYSIDE HOME.

She has two small, sharp saws with which to cut the wood. She can make paper.

She saws the wood into a fine dust. Then she mixes it with glue from her mouth.

When she takes it home, she spreads it out thin with her feet. It dries into fine, gray paper.

With it she papers her house, to keep her baby warm and dry.

Mrs. Wasp is cross, but she is wise. She has a long sting. She kills, or puts into a deep sleep, the caterpillars that she takes home.

She is never idle. 


\section{, $2 \operatorname{IESSON}$ XTI.}

\section{WHAT MRS. WASP CAN DO}

How does Mrs. Wasp make paper? First she finds a piece of dry, old wood.

She cuts off bits of wood, Iike fine, soft threads. She wets these with a kind of glue from her mouth, and rolls them into a ball.

Then, she stands on her hind legs, and with her front feet puts the ball between her jaws. She then flies to her nest.

She uses her tongue, her jaws, and her feet, to spread the ball out thin. On her hind legs she has flat feet, to help her lay down the paper.

She lays one sheet of paper on the other, until it is thick enough to make a nest. Some wasps hang these paper nests in trees.

The nests are round, like balls, or are the shape of a top. At the bottom of each you will find two doors.

Some wasps make paste-board. The wasp that builds in a tree does not live alone.

She has in her home very many paper rooms. They are like cells in a honey-comb. 
She can make wax. She puts a wax lid on the cells.

She can make varnish, to keep the cells dry.

One kind of wasp is a mason.

Hor house is made of mud. She brings mud in little balls, and builds a house.

In the house, she puts a bal,y wasp. She puts in little spiders for him to eat.

A hornet is a kind of wasp. We may call him Mrs. Wasp's cousin. Hornets catch and eat flies. There is a black wasp that is called a mud-dauber.

She builds a little mud house. I know a boy who broke one of these mud houses thirty-two times.

The wasp built it up each time. One of these mud-wasps built a house ten times on a man's desk. Each time that he broke it up, she built it again.

This kind of wasp does not leave her baby alone.

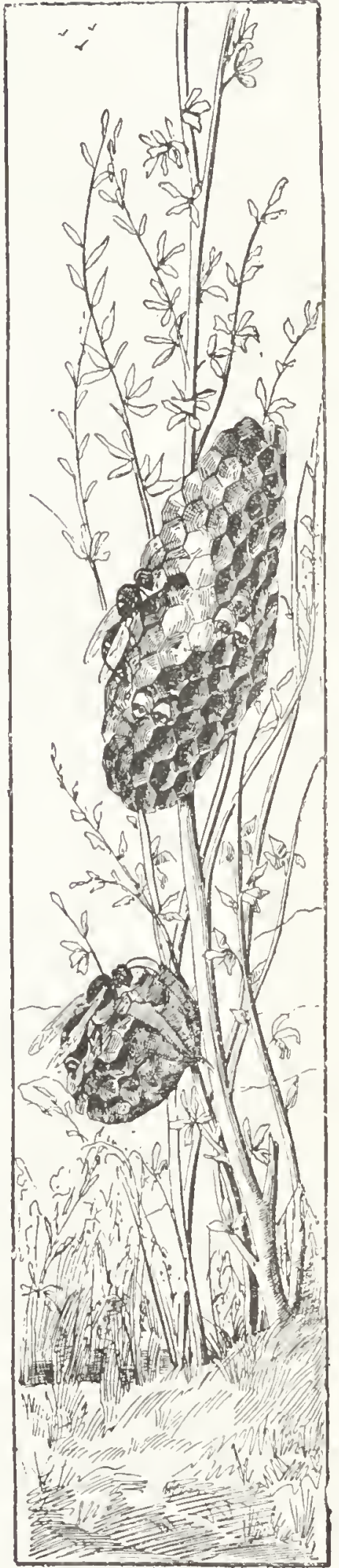

A PAPER HOUSE. 


\section{LESSON XIII.}

\section{A LOOK AT MRS. WASP}

Mrs. Wasp's colour is blue-black. She has yellow marks. She has four thin wings. Two are large and two are small.

The front wings are the large ones. Her wings lie close to her sides when her body is at rest. The wasp looks as if she had two wings, not four. The two under ones are hooked to the upper ones. Her eyes are set close to her head. They are large. They have a notch or dent in them. She has two long wands, called feelers, on her head.

They are made in joints. She touches things with them.

Her body is in three parts. The first part is the head, with the eyes and mouth.

The next part is thick and short. The hind part is long and slim.

These two join at a point. It looks as if the hind part might drop off, but it never does.

Mrs. Wasp has a long, sharp sting in her tail. The wasp's sting is like two fine saws. 
A drop of poison runs through it from a bag.

You need not fear Mrs. Wasp. She does not sting if you let her alone.

She has six legs. The legs and wings are set on the part of the body that is next the head.

She uses her front legs for hands. The body of the wasp is hard, and made of rings like scales.

Mrs. Wasp uses her jaws to cut up wood for paper. She does not need them to eat with.

She eats honey. When her baby eats spiders and caterpillars, it does not chew them.

It sucks out their juice.

Wasps bite fruit and spoil it. They are cross, and fight. They kill bees for their honey.

All wasps are not of the same colour.

The wasp that leaves her baby alone is the hermit wasp. There is a wasp of a rust-red colour.

\section{$-0050200$ \\ NLESSON XIV. \\ MRS. WASP'S YEAR.}

I will now tell you of a wasp that does not live alone. This Mrs. Wasp takes good care of her babies. She is called the social wasp.

While it is winter Mrs. Wasp hides. She does not like the cold. 


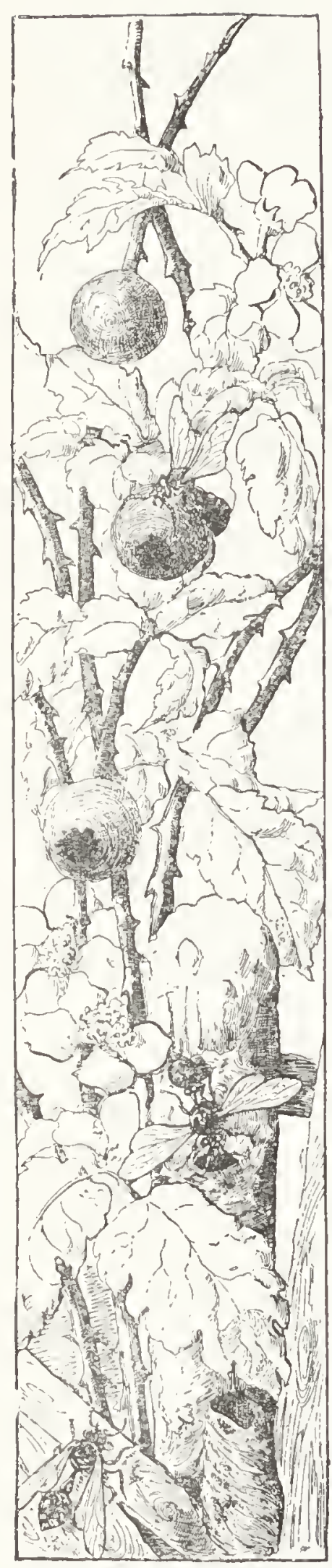

ROOMS TO LET.

Most wasps die in the winter. Only a few live to come out in the spring.

The first thing Mrs. Wasp does in the spring is to build a new house. She does not use an old house.

She puts her eggs into the house, with some food.

When the young wasps grow up, and come out, they help build. More cells are put into the house. An egg is laid in each cell.

The egg grows into a grub. Then the wasps feed it.

They bring it honey. The baby wasp has no wings nor feet.

It has to be shut up, to grow into a true wasp. When the time comes, the wasps put a wax lid upon the cell.

At last the new wasp eats off the lid, and comes out, a full-grown wasp. Wasps work hard all the time. They fly about for food, and for stuff to make paper, wax, and vamish and glue. They have homes to build, and little wisps to rear. 
They seem to know they must nearly all die, when frost comes. When the cold begins, the old wasps look into the cells.

They kill all the eggs, grubs, and half-grown wasps that they find there. Why do they do that?

Do they not seem to love the baby wasps? Yes. They kill them quickly to keep them from dying of hunger and cold. Is not that a queer way to show love?

Some wise people do not feel sule that the wissps kill the little ones in this way.

Do not forget that the wasp does not grow after it gets its wings and leaves its cell. When it comes out it is full grown.

When it is a fat, round, wingless grub it is called a larva. When it has changed its shape, and lass wings, it is called a pupa.

Some call the pupa a nymph. Are those very hard words?

\section{iVESSON XV.}

MRS. WASP AT HOME.

There are many kinds of wasps. There are mud wasus, which make mud houses.

Lonely wasps build alone in the ground, and dig 


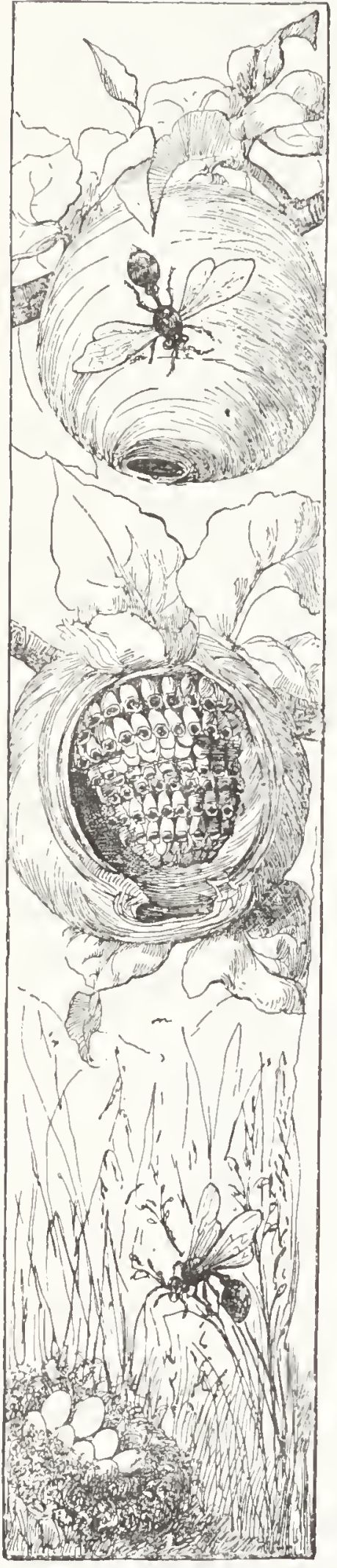

ROCK-A-BYE BABY. holes in the sand. They throw the sand back between their hind legs.

Did you ever see your dog dig a hole? The wasp digs in the same way as the dog.

Sand wasps make tiny earth houses on walls and fences. Tree wasps hang great paper houses upon the branches or twigs of trees. Rust-red wasps do not build houses for their cells. They make fine paper cells, and hang them with the open part down, in some safe place.

They varnish the cells to keep them dry. In a cold land, the wasps build in barns, attics, hollow trees, or in the ground.

In warm lands, they hang a bunch of cells out in the open air, on trees or vines. One day I found a wasp's nest in an old tin can. There had been paint in the can. The wasp had made a stem of paint. She used her feet to twist it into a 
stiff rope. Upon that, for a stem, she built a nest like a white flower.

She put a cell upon the stem, and six cells around that one. In each cell was a wee, white eggr.

The eggs grew to fat grubs. They had black heads. Then Mrs. Wasp fed them. She went from one cell to the other, and fed her grubs, just as a bird feeds its young.

Mrs. Wasp also makes a pap of flies and fruit, and gives it to her young.

Wasps are very neat. They keep their nests clean. They use cells more than once.

But they make new nests each year. One kind of wasp is called the White Face.

All wasps have a clean, shining coat, and a fierce look.

Wasps do not bite or chew food; they suck out the juices of fruit and insects.

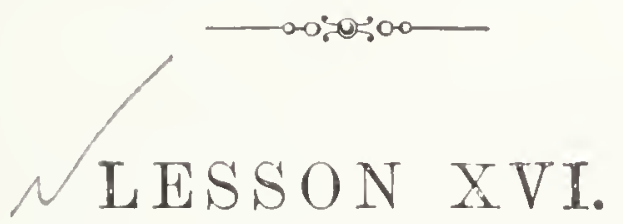

REVIEW.

Winere, and how, does Mr. Crab make his house? Where are Mr. Crab's bones?

Where are yours? Will you tell me how Mr. Crab gets on his new coat? 
Tell me some of the kinds of crabs that you know of. What do crabs eat?

Why does one kind of crab steal a shell? Tell me about a crab's eyes.

How is the crab made, which likes to swim on the deep sea? What is a sea tide?

How many tides are there each day? How do little cralls grow?

Where do cralss hide, when they are afraid? What animals catch and eat crabs?

Of what use are crabs? Did I tell you that some crabs eat sea-weed?

What is a wasp? How many legs and wings has Mrs. Wasp?

How is her body made? Why do her two wings on cach side seem one?

'Tell me what kind of houses wasps build. What can wasps make?

How do baby wasps grow? Tell me how wasps make paper.

What else do you know about crabs and wasps? What can you say about a wasp's sting? How aioes the wasp eat? 


\section{LESSON XVIT.}

\section{THE BEE AND THE MAN.}

Did you ever see a hive of bees? Are you afraid of bees? You need not be afraid of them.

They do not often sting those who let them alone. There are some people whom bees never sting. Do you see how small the bees are?

Do they not move very quickly? Are not their cells very small? Now I will tell you a strange thing. The man who knew most about bees was a blind man! His name was Huber. He lost his sight when he was a boy.

He loved to study. Most of all, he loved to study bees. From a boy, he had a friend. She was a kind girl. She, too, loved to study. When she grew up, she became Huber's wife.

Huber was not poor. He had a nice home of his own.

He had a man to live with him and wait on him. Huber, and his wife, and the man, would go and sit by the bee-hive. They read to Huber all the books about bees that had then been made. Then they would watch the bees, to see if they did the things that were told in books. 
When they saw the bees do other things, they told Huber. Then they caught bees, and studied the parts of their bodies. Ask your teacher what kind of a glass they used ${ }^{1}$ to see the bee with. The wife and the man told Huber all that they saw. He thought it all over. They watched the bees, year after year.

Huber worked fifteen years. Then he made a great book on bees. IIe told his wife what to write. He lived to be very old.

It is both from books, and by your own eyes and thought, that you may learn these things. You must watch if you would know. Give time and work to this study.

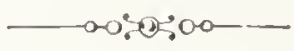

\section{LESSON XVIII. \\ HOW THE BEE IS MADE.}

There are many kinds of bees. The chief of them all is the hive bee. What does the hive bee make for you to eat?

In each hive there are three kinds of bees. The queen bee is the first. She rules all, and she is the mother of all.

1 The inside of a gold watch-case, held at angle $45^{\circ}$, is a good magnifier. The teacher should explain a little about the microscope. 
The queen bee does no work. She lays eggs in the cells. The father bee is called the drone. He does no work.

Who, then, builds so many fine cells? Who lays up so much honey? Who feeds the baby bees? The small, quiet, brown work bees do all that. In each hive there is one queen bee to lay eggs. And there are the drone bees, who hum and walk about. And there are more than you can count, of work bees, to do all that is done.

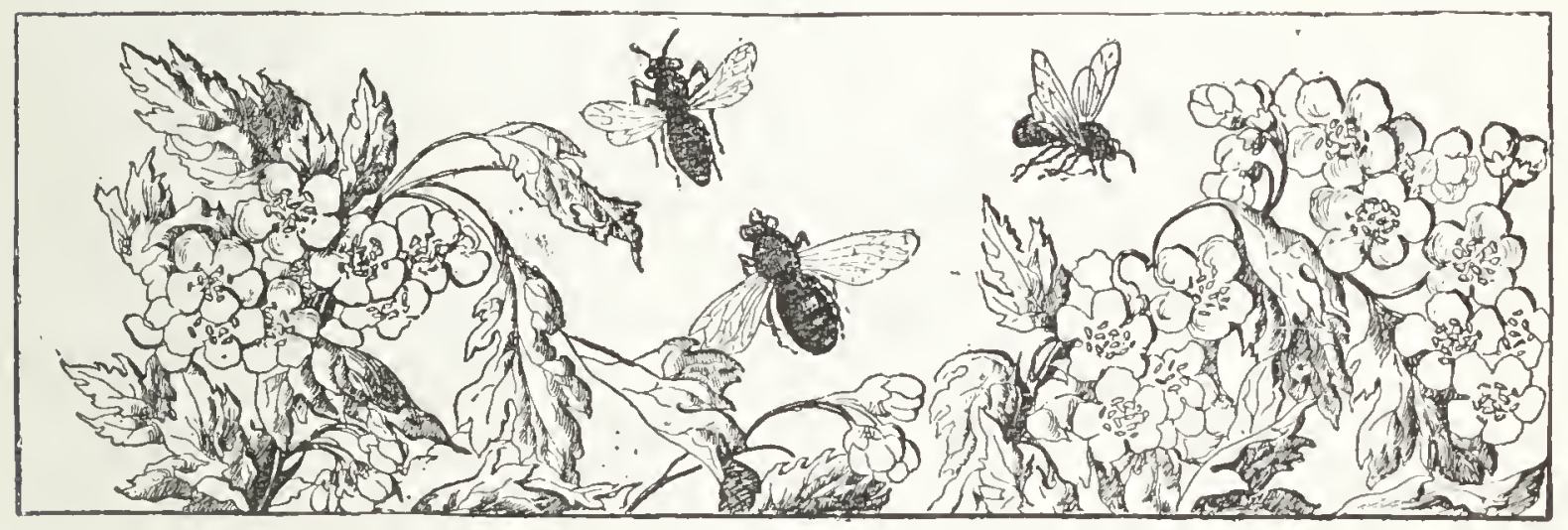

WORK AND PLAY.

How does a bee grow?

Like the wasp, the bee is first an egg. Then it is a grub, or a worm. Then, shut in a cell, it gets legs and wings, and turns into a full grown bee.

The bee is formed of three parts, as a wasp is; but the body is not so slim. The parts are put close to each other. The bee has six legs, and four wings, and many eyes set close like one.

The bee has many hairs on its legs and body. These fine hairs are its velvet coat. 
Part of the bee's mouth is a long tongue.

It can roll this up: it uses it to get honey from flowers. The body of the bee is made of rings. The drone bee has a thick body, a round head, and no sting.

The queen bee has a long, slim body. Her wings are small. She can sting: so can the work bee.

The work bee is not so large as the other two, but it has large wings. The work bee must fly far for food or wax. The queen bee stays at home.

\section{LESSON XIX. \\ THE BEE AT HOME.}

LET us look at a work bee. There are two kinds of work bees. Nurse bees take care of the baby bees.

The wax bees build the house. Let us look well at the wax bee. See its body.

Here are the rings, and here are the scales of wax on each ring. The wax is made in the bee from the honey or sweet food that the bee eáts.

In the bee's body are two bags.

Into one bag it puts the honey that it gets from flowers. It takes this home and puts it into the cells. What goes into the other bag feeds the bee and makes wax. 
Look at this bee's legs. On each leg is a basket, a brush, and a tool with which to pinch and press the wax into the cells.

When the bee goes into a flower, it gets covered with dust. The brush on its legs takes off this dust from the bee's coat and puts it into the basket. That dust is to feed the young bees.

With the tool it strips the scale of wax from the

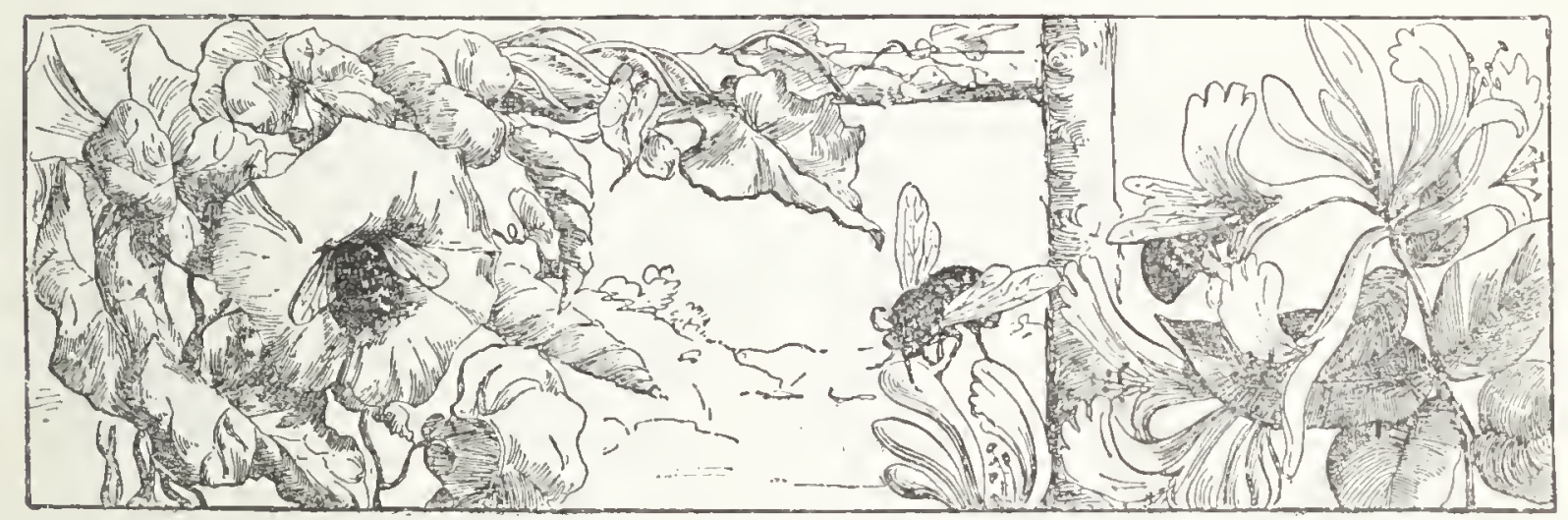

SWEETS TO THE SWEET.

rings on its body. Then it takes the wax in its mouth and lays it to build the wall of the cells. Did you ever see a man lay bricks on a wall? The bee builds her walls very much as the man builds his. When the work bees make cells, they first lay down a thick sheet of wax. Then they build upon this little wax boxes, each with six sirles, set close to each other. When the boxes are as deep as they wish them to be, the bees fill them.

Let us see what they do with the cells. Some of the 
cells are for the dust, or food, called bee-bread. Some cells are for the baby bees to lie in.

Some cells are for honey. The queen puts eggs in all the cells that are for bees. The nurse bees put in flower dust for the baby bees to eat.

The wax bees build the cells and get honey. The wax bees have pockets for wax. The nurse bees have only smail pockets.

The queen bee and the drones have no pockets.

\section{$-0.00000$ \\ IESSON XX. \\ THE BEE BABIES.}

A BEE does not live more than three or four years. The work bees know that some of the grubs must grow to be queens, others to be drones and others work bees. They make for the baby queen bee a large, round cell.

In each hive there are five or six cells for these baby queens. Then the nurse bees feed the grubs. They give the baby queens all they can eat of very nice food.

The baby work bees get only plain bee-bread. The work babies are in small cells. The grub of the new queen bee grows large, and eats as much as it wants. 
The grub of the work bee gets little food, and is then shut in its tight cell, to turn into a bee. After a time the grubs shut in the big cells turn into queen bees. They begin to sing a song.

The queen bee hears it. She knows that more queen bees will come out. Then she gets cross.

She runs at the cells, to try to kill the new queens. The work bees all stand in her way. They will not let her kill the new queens.

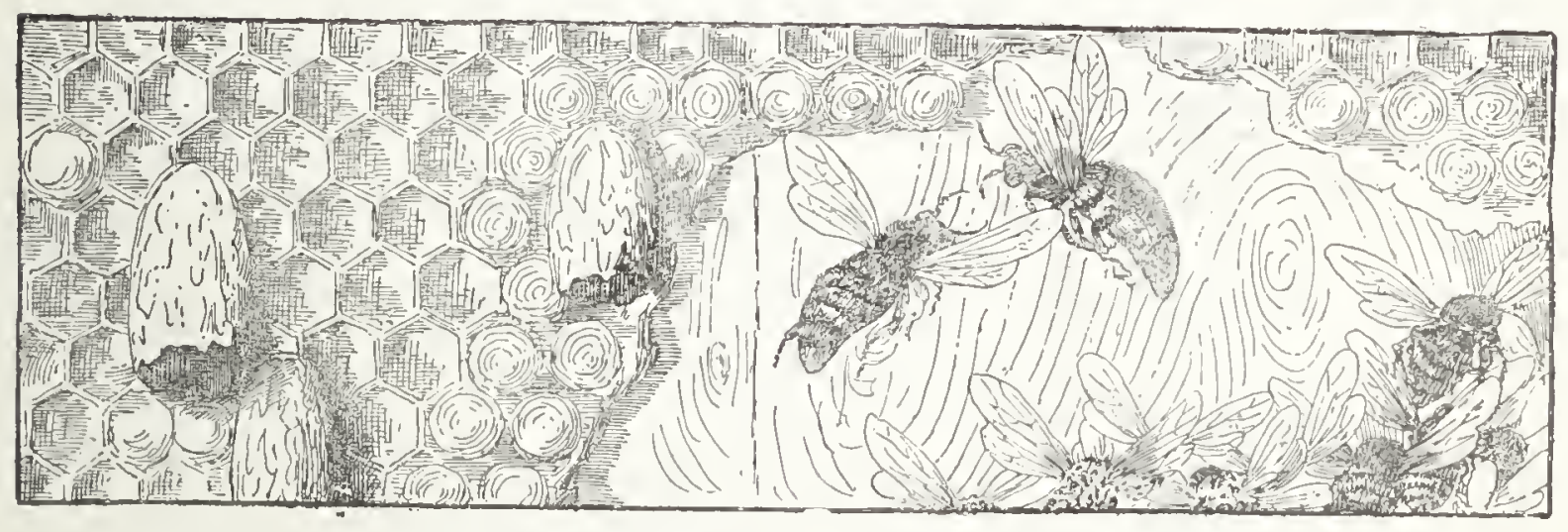

BATTLE ROYAL.

But there can be only one queen in a hive at one time. So the old queen says, "Come! I will go away! I will not live here any more!"

Many of the old bees say, "We will go with our queen." Then they fly out of the hive in a cloud. They wish to find a new home.

Did you ever see bees swarm? They may fly far away, or they may light near by.

They hang on a vine, or branch, or stick, like a bunch 
of grapes. Can you put them into a new hive? Yes.

Drop them softly into a new hive where there is a piece of honey-comb In a few hours they are calm. Then they go to work.

The work bees begin to make cells. They spread wax. They build walls.

If a young bee lays a bit of wax wrong, some old one takes it up and lays it right.

\section{LESSON XXI. \\ THE BEE WAR.}

After the old queen goes out in a rage, what do the rest of the bees do? They all keep still, but they look to the cells where the new queens sing. Then one new queen breaks off the lid of her cell and comes out.

She lifts her head, spreads her wings, dries her legs. Her legs are like gold. Her dress is velvet and gold.

She is fine! The bees fan her and feed her. But just then a cell near by opens, and out comes one more new queen!

This will not do. Two queens do not live in one 
hive. The two queens see each other. Then they rush and begin to fight.

If they stop the fight to rest, the work bees make them keep on. At last one of them stings the other near the wing, and kills her.

Then this strong queen runs to the other cells, where the baby queens lie. She tears off the wax lids and stings each new queen bee. Then it dies.

Now the strong queen is the one true queen of the hive. Her rage is at an end. The bees come to her and touch her.

They are proud of their fine, new queen, and love her. They carry out all the dead bees from the hive, and in great joy build new cells. The queen bee leaves the hive but twice.

A few weeks after she is made queen, the work bees let her go out once into the sun and air. But her wings are very small. She cannot fly far.

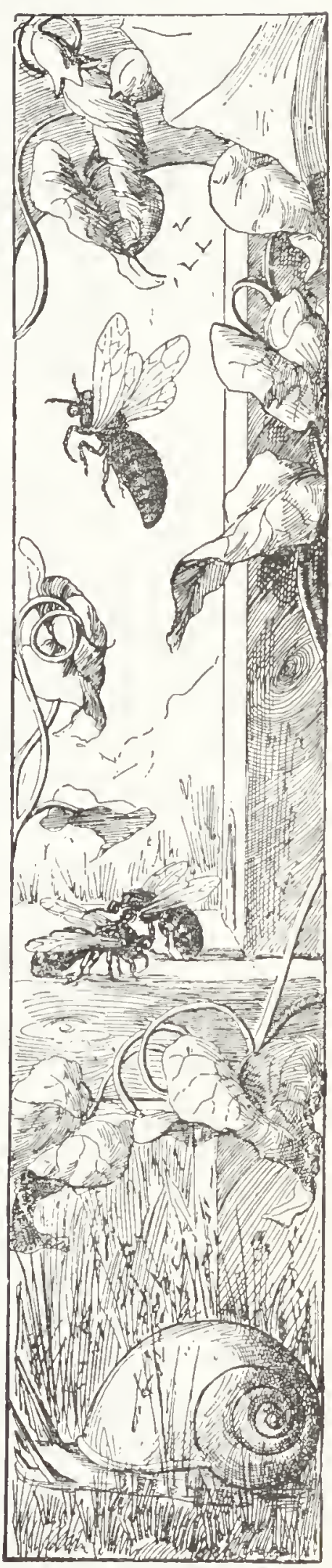

FIRST FLIGHT, 
She has no bag for dust. She does not need to get honey. All she need do is to come home and lay eggis.

She does not go out again until the next year. Then she leads off a swarm of old bees, and leaves the hive to the next new queen bee.

\section{LESSON XXII.}

\section{THE BEE'S WORK.}

You know how the new queen bee is made and how she lives. Now let us see how the work bee gets on. The work bee in its small cell does not grow so large as the queen bee.

But it lias larger wings. When it is a true bee, it pulls or breaks off the cap of its cell and comes out. It is wet and cold and weak.

But near by is a cell, open, and full of honey. 'The new bee takes a nice meal. Then it goes out of the hive into the sun.

The other bees come to it, and touch it with their feelers. They lick it with their tongues, to smooth its brown coat. They help it spread its wings.

Then off it goes to get honey and flower dust. It knows how at once. It does not need to learn. It finds its way. It knows the right flowers. It tries 
to keep out of the way of things that will hurt it.

What colour do the bees like best? They like blue best, and red and purple next best. They like flowers of a sweet smell, and all flowers that have honey. They bring home dust of flowers, honey, and a kind of gum. The gum is to line the cells and to help make them strong.

If a queen bee dies, and all the baby queens are also dead, what can the bees do?

They take a baby work bee and make a queen. Can they not live if they have no queen? No, not long, there will be no eggs laid.

How do they make a queen of a work bee? They pick out a good grub. They put it into a round queen cell.

They feed the work grub with queen food, or "royal jelly." When it grows up, it is not a work bee, but is a queen.

\section{$\longrightarrow 0.9500$ \\ LESSON XXIII. \\ THE WISE BEES.}

In the bee-hive all is not peace and joy. Foes come in and try to kill the poor bees. Who are thcse foes? A caterpillar may come into the hive to live. The 
bees do not like him. He is not clean; he is in their way.

Slugs also come in. Snails and moths also come to steal the honey. When the foe is a small fly or slug, the bees kill it and take it out.

But a large worm or slug they cannot take out. What do they do then? They kill it, if they can, with their stings.

Then they build over it a tomb, or grave, of wax and

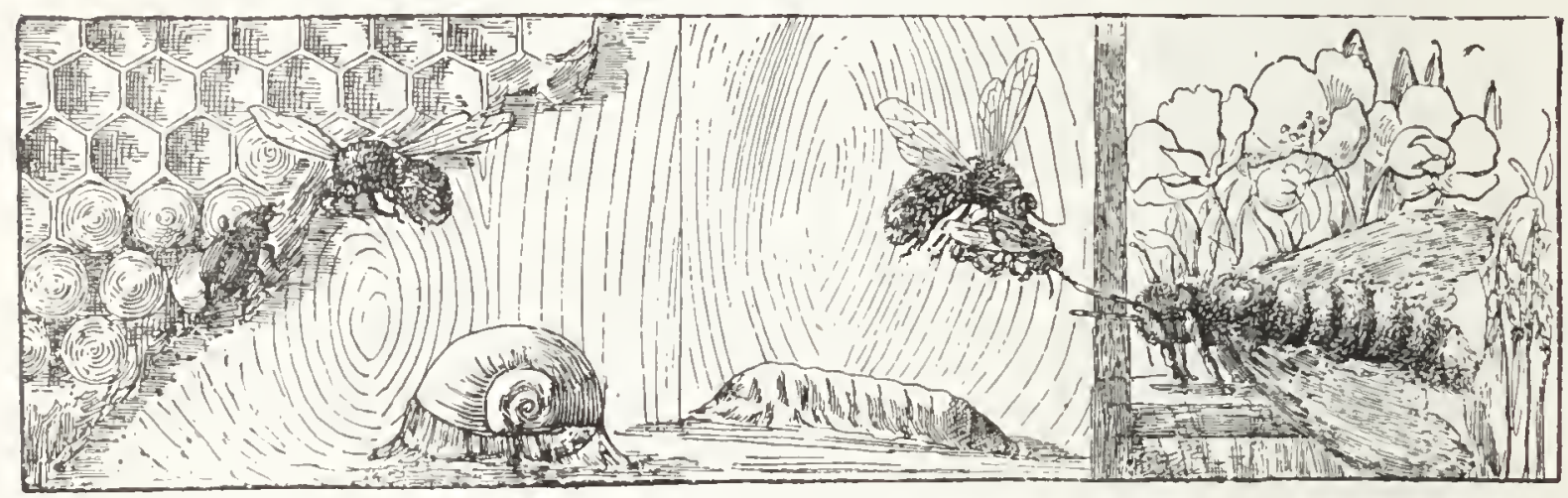

A FOE AT THE GATE.

gum. It is in this way they keep the bad smell from the cells. If a snail comes in, they take this same strong gum and glue him to the floor. Then he must die in his shell. If a strange queen flies in, they will not sting her.

But she must not stay. So the work bees form a ball about her, until she dies for lack of air.

I have told you how wasps kill bees. Birds eat bees. Some birds break into the hive to get honey. Bears like honey. 'They break up wild bees' nests. 
Hens and toads eat bees. Moths make the worst trouble in bee-hives.

In June or July, the work bees kill all the drones. They do not wish to feed them when it is cold.

Bees lay up honey to eat when the flowers are dead and gone.

In the winter, bees sleep most of the time. They need some food to eat when they rouse. As soon as spring comes, they come out and go to work.

\section{LESSON XXIV. \\ EARTH BEES.}

Do all bees build in hives? No. IVild bees like to build in hollow trees.

In hot lands, some bees build in holes in the rock. Swarms of bees that leave hives find odd places to live in. I knew of a swarm that found a hole in the roof of a house.

The bees got into the roof and lived there five years. When a man took them out, they had two big tubs full of comb. Is it not odd that bees can make so much wax from their small wax-bags?

Did you ever find in the earth the nest of a humblebee? The humble-bee queen works. Humblebees dig holes in the earth with their front feet. 


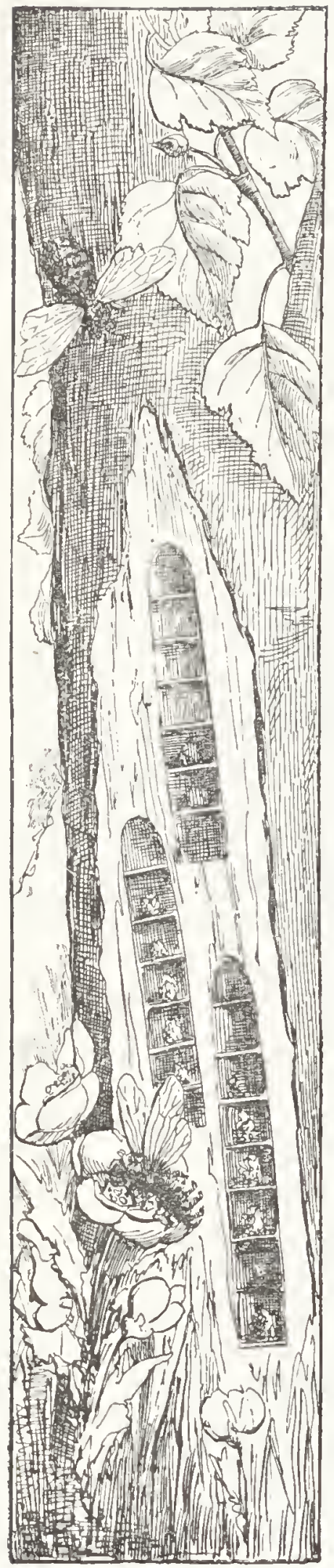

A CITY IN A TREE.
When they have made a hall and a room, they make a nest. It is of grass, or leaves, or hay, cut fine. They lay eggs in the nest.

They make honey in large combs. The combs are more soft and dark than those which the hive bee makes. Field mice and moles eat these bees and their combs.

One little bee, that lives alone, saws out a nest in a post or tree. She makes one room over the other. In each she puts an eggon and food. She seals the door up with a paste made of savdust. Then she groes off and dies. The next spring out come the new bees.

They know how to get food and make homes, just as the mother did. One kind of bee makes a house much like an ant-hill. She makes a long hall.

From the hall she opens small rooms. In each room she puts food, in a ball like a pea. Then she lays an egg by it, and leaves the small bee to grow up alone. 


\section{LESSON XXV. \\ OTHER BEES.}

ONE bee is called a mason bee. She takes fine mud or clay, to make a cell. The cell is the shape of an urn. Now and then, she builds this urn in an empty snail shell.

One kind of the mason bees is of a dark green colour. Mason bees are very small. Some mason bees live in holes in the ground. In the hole they make a clay cell like a box.

But they are so neat that they do not like to see a mud wall. What does the bee do to her wall? She cuts out bits of nice, soft leaves, and lines her cell! Some bees take bits of green leaves, as of the plum tree.

But they like bright color best. One kind of bee uses leaves from the flowers of roses. She glies them all over her cell. Then she puts in food and an egg.

Do you not think the new bee will like its gay, pink cell? One kind of bee likes red poppy leaves best. She cuts the bits of leaf quite small.

There is a bee in Brazil, which makes a large nest, like 


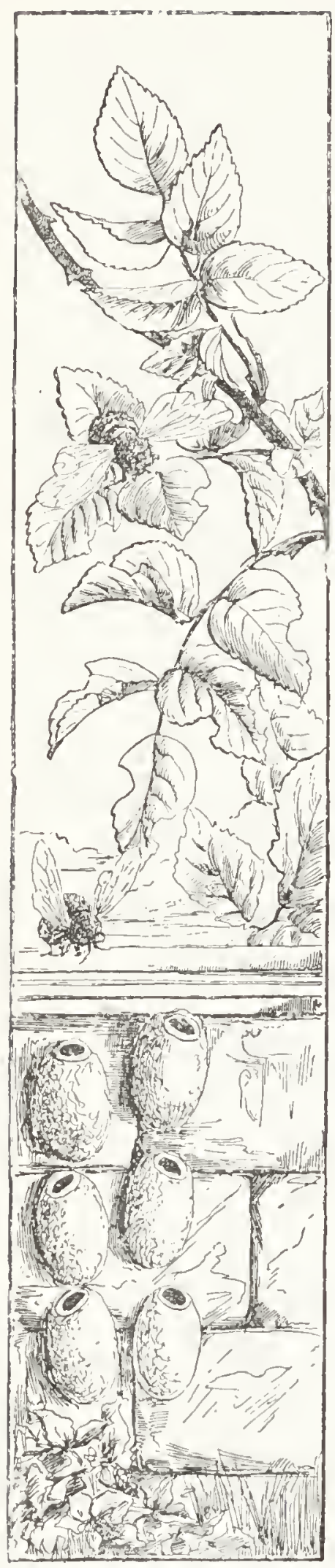

a great bag. It is full of round balls. The balls are full of honey. The wax and honey of this bee are of a dark colour. One kind of bee has no sting. Would you like that bee best?

The tree bee is also called the wild bee. This bee takes an old tree with a hollow trunk. It cleans out more and more of the old, dead wood, and builds nice combs.

A tall tree may be full of combs, from root to top. In such a tree, more than one swarm will live and work. Each swarm has its queen, and keeps in its own place.

Smoke makes bees fall, as if dead. People drive bees off with the smoke from a fire of wood or paper.

JACK OF ALL TRADES. 


\section{LESSON XXVI. \\ MORE ABOUT BEES.}

Would you like to own bees? Once I knew a boy who had some bees. He kept them in a room, at the top of his house. He left the window open, and the bees came and went as they chose.

A swarm of bees does not cost much. Each year it may gain for you as much, or more than it cost, by honey, and a new swarm.

If you live in the city, you cannot so easily keep bees.

Why not?

They could not find the right food.

They reed to fly in the field or in a garden, so that they san get the honey and the yellow dust of flowers. They need to fly where they can get the thick gum from trees to line their cells.

If you have a hive of bees, you should learn to watch them well. Like Huber, you may find ont some new things. We do not yet know all about bees. We could learn more than is now known about drones.

If you stand by a hive, the bees will not hurt you 
if you keep still, and do not get in their way to the door as they go in and out.

Bees lay up for winter more honey than they need. So the bee-keepers take out much of it to eat or to sell. But they must leave some for the bees. If too much comb is taken out, the bees must be fed. You can give them sugar or some sweet stuff. Bees like flour made of peas.

They cannot feed young bees if they do not have sweet dust or flour. They cannot make wax if they have no sweet food. They cannot line their cells, nor seal them well, if they have no strong gum from trees. I know some people who think bees like to hear a song, and so sit near the hives and sing to them. But bees, really, love colour, and sweet smell, and nice tastes, and do not care much for any noise.

\section{$-0.0: 000$ \\ LESSON XXVII.}

\section{THE SPIDER AND HIS DRESS.}

Flies, wasps, bees and ants are insects. Insects have six legs, and their bodies have three parts. An insect is at first a tiny egg. From the egg comes a grub, and the grub turns to a full-grown wasp, or fly, or bee. 
When it first gets its legs and wings, and comes out of its cell or case, it is as large as it ever will be. Insects do not grow after they get wings. The small fly does not grow to a big fly, nor the small bee to a big bee. The first size they have when they come out is the size that they keep.

But the spider is an insect of another kind. The spider lays eggs. Out of the eggs come little spiders.

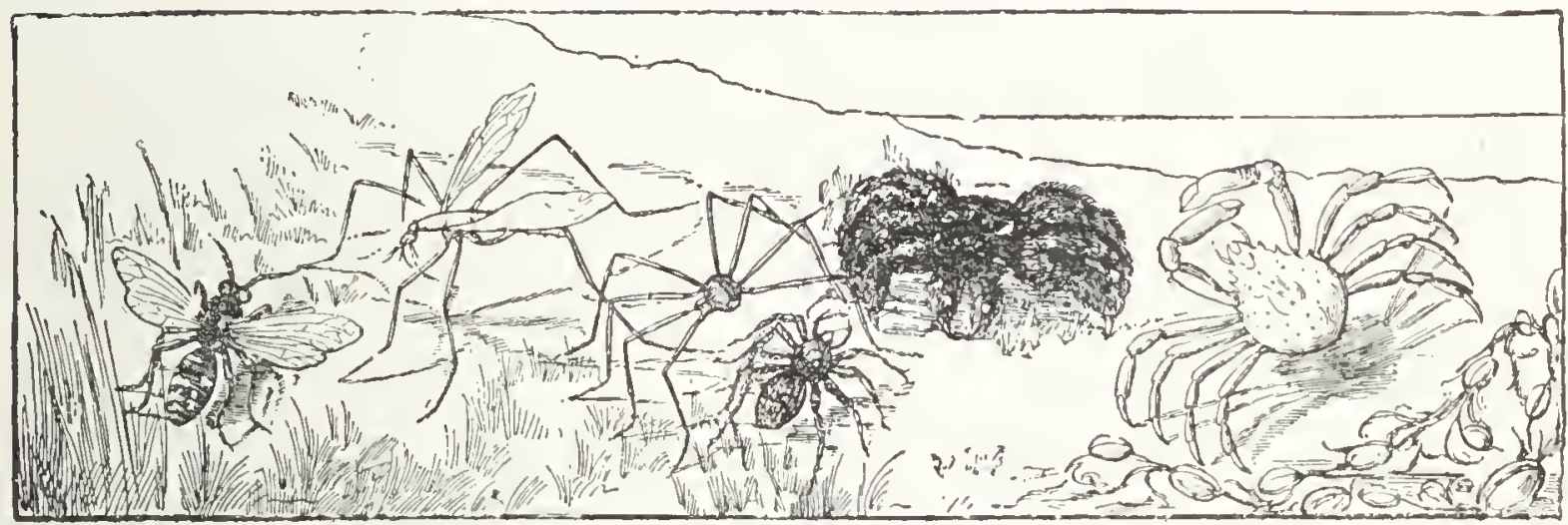

A CHAIN OF EVENTS.

They grow to be big ones. The spider changes its size, it grows. It casts its skin.

The body of the insect is hard, and is made in rings. It cannot pull its coat off to get bigger, as a crab can. The spider's body is soft. Its skin is tough; it changes its skin often when it is very young.

The spider has eight legs instead of six, and most spiders have eight eyes. The spider's body is in two parts. The poison is not in a sting in the tail. It is in the base of the two jaws. 
The spiders are somewhat like crabs; somewhat like other insects, as the daddy-long-legs. The real daddy-long-legs is a fly with long legs. A spider that has just such legs is also called a daddy-longlegs.

The front part of the spider's body is not so large as the hind part. The front part has all the eight legs and the head.

The spider never has any wings. But he has two small front legs, or hands, with five joints. He uses them to feel with, and to take his food.

You will see on the head of the spider two short fangs. They are its jaws. They have the poison in them. They are used to bite.

The claws on the eight feet of a spider are very much like a lion's claw. The claws have a brush of hairs on them.

The spider can walk up a wall. The brush on his feet will not let him drop off. He uses his legs to jump and to walk, and to guide his thread when he spins. Spiders spin webs. The hind part of the spider is large and round. It has six small, round tubes. Each of these tubes is made of many very small tubes. What are they for? They are to spin this web. What is the web?

In the tube is a kind of glue. When it is drawn out into the air, it gets hard. It is then a fine silk, 
and as it comes out it is woven into a net which we call a web. All spiders spin webs.

Spiders are of all colours. Their dress is like velvet. It is black, brown, red, and gold. It is in stripes and spots. The spider is like a king in his rich dress. The eight eyes of the spider cannot move. They are set so that they can see every way at once.

While the spider is growing, he pulls off his dress as Mr. Crab does. The crab's bones are his coat. The spider has no bones, but his skin is hard and tough, and before the baby spiclers are two months old, they shed their coats three or four times.

We say they moult when they do this. They spin a bit of line to take firm hold of. Then the skin on the front part of the body first cracks open; then after this the skin on the hind part falls off; and by hard kicks they get their legs free.

The new skin is fine and soft but soon grows firm and toligh.

\section{-as:orom \\ LESSON XXVIII.}

\section{THE SPIDER AT HOME.}

Tne spider, like the wasp, is busy all the time. It is not cross like a wasp. The bite of a spider does not do a man or a child much harm. A 


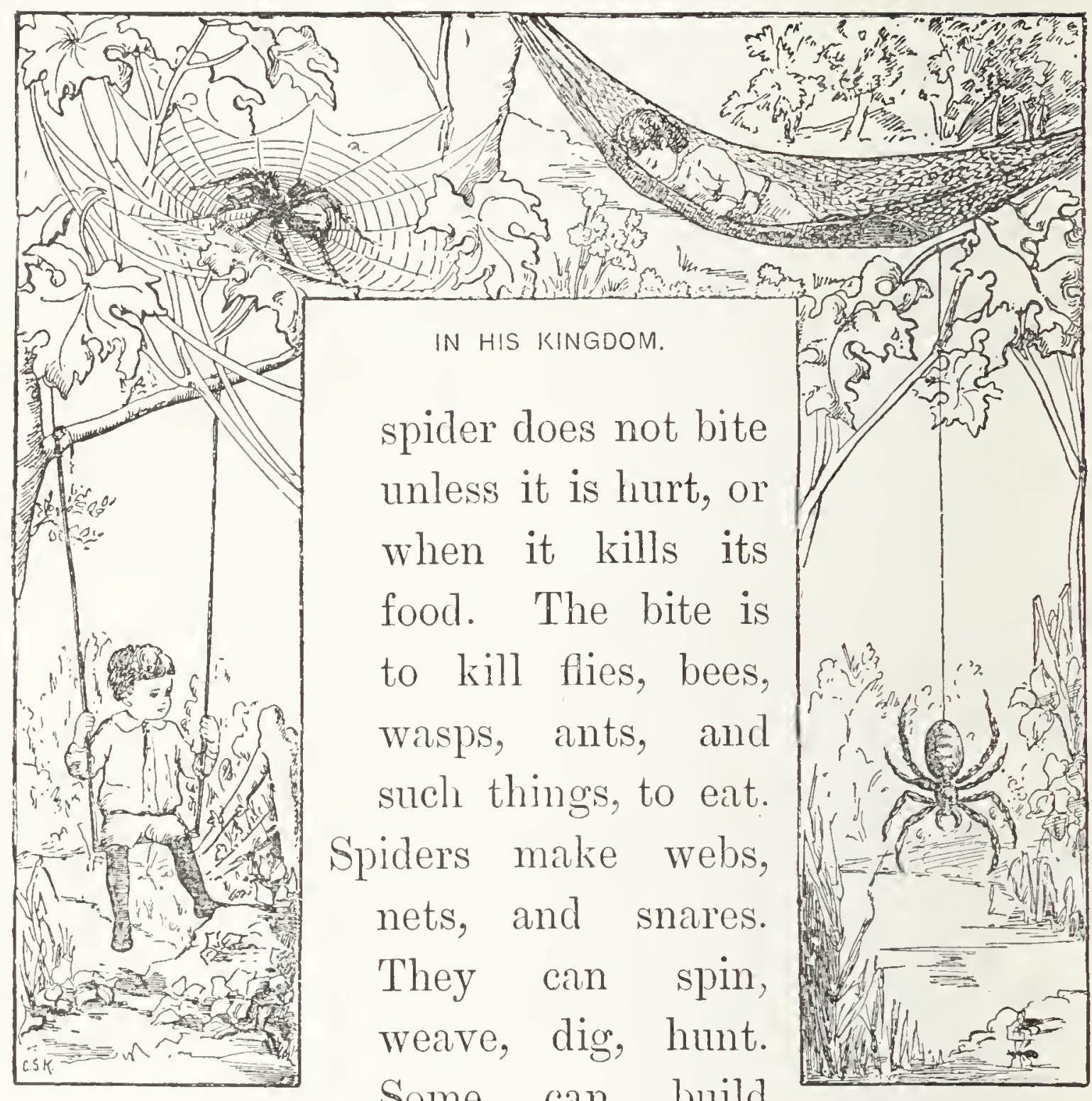

Some can build

rafts, and others make mud houses.

Their webs are to live or lie in.

The nests are for baby spiders. The snares are to catch food. The silk of the web is very fine, but it is very strong. It will hold up a big, fat spider.

It will hold fast a wasp or a bee. Do you see the spider on his thread? It is his swing. He can swing as the boy does in his rope swing. 
Do you see the spider lie at rest in his web? Do you see the child rest in a web made of string? How does the spider make his web?

First he finds a good place. Then he presses the end of the tube he spins with, and makes a drop of glue fast to a wall, or leaf, or stem. Then he drops away; and as he goes, the glue spins out in many fine streams, which unite into one, and turn to silk-like thread. If he does not find a good place to make his web fast, he can climb back!

How can he climb back? He runs up his line as fast as he came down. If you scare him, he drops down on his line like a flash. It will not break. If you break it, he winds up the end quickly. Then he runs off to find a new place to which to make it fast.

The long lines in the web are called rays. The spider spins the rays first. The rays are spread out like the spokes of a wheel.

Webs are of many shapes. You often see the round web.

The spider guides the lines with his feet as he spins. He pulls each one to see if it is firm.

Then he spins a thread, round and round, from ray to ray, until the web is done. 


\section{LESSON XXIX.}

\section{THE LITTLE NEST.}

Trie web of the spider is made of two kinds of silk. The silk of the rays is smooth. The silk that goes across the rays has tiny drops of glue on it. This makes the line stick to the rays.

Mrs. Spider begins her lines at the outer edge. They are laid nearer to each other as she gets to the centre of the web. When all is done, she is in the centre, and does not need to waik on her new web. She has a nest near her web.

From the nest runs a line. Mrs. Spider can sit in the door of her nest, and hold the line in her claw. When a bee or fly goes on the web, the web shakes. She feels her line move. Then she runs down the line and gets the fly or bee, and takes it to her nest to eat.

But before she takes the prey to her nest, she kills or stuns it. Then she winds some fine web about it. She makes a neat bundle of it, and then carries it off.

You can make Mrs. Spider run down her line if you shake the web a very little with a bit of grass 
or stick. She will run out to see if she has canght a bee or a fly.

The nest of the spider is made of close, fine silk. It is like soft, nice cloth.

In shape it is like a ball, or a horn, or a basket. Each kind of spider makes its web in the shape it likes best. In the nest the spider lays her eggrs in a silk ball. The eggs, at first, are very soft. After a time they grow harder.

More than two spiders never live in a nest. Often a spider lives all alone. Spiders are often apt to bite off each other's legs. A spider can live and run when half its legs are gone. But it can get a fine new leg as a crab can.

When the baby spiders come out of the egg, they must be fed. The mother takes good care of them. They grow fast. When they are

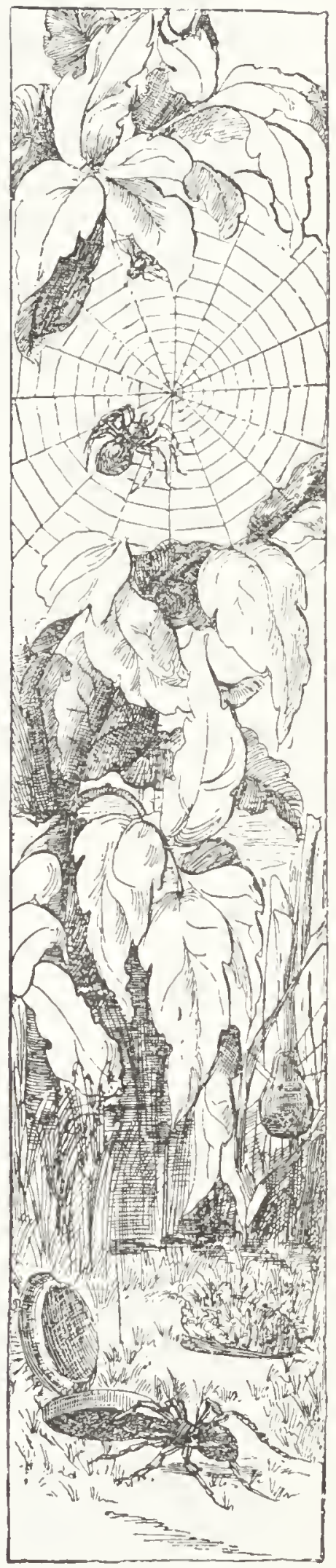

TRAPS AND SNARES. grown, they go off and make 
their own webs. Sometimes the eggs are left in the silk ball all winter. The baby spiders come out in the spring.

Then the old ones are dead. But the young ones know how to hunt and to spin. The very young spiders do not have so rich a dress as the old ones. The hairs of their coat are not so thick at first.

The soft, silk-like coat, with its rich colour, is the only beauty a spider has. People do not like his long legs and his round, soft, bag-like body. Still, some people who watch spiders learn to like them very well.

\section{$\longrightarrow+0.0500-$ \\ LESSON XXX. \\ THE SPIDER AND HIS FOOD.}

Sore people say that they hate spiders. Why do they hate them? "Oh," they say, "they are so very greedy!" Well, a spider must eat a great deal, or he cannot spin his web.

His food makes the glue that makes the web. Spiders work hard. So they must eat much.

"But they bite." They will not bite you if you do not hurt them. If they do, the bite will do you no harm. They bite insects to kill them. 
Do you not eat fish, meat, and birds? Who kills this food for you? "But the spider is not pretty." True, his shape is not pretty, nor are his long hairy legs pretty. But see his fine black or gold coat!

If he is not pretty, he is wise and busy. Webs are very pretty, if spiders are not.

Spiders eat flies and all kinds of insects. When a fly is fast in a web, he hums loud from fear.

The spider will eat dead birds. One kind of spider kills small birds to eat.

There is a spider that lives on water. He knows how to build a raft.

He takes grass and bits of stick and ties them up with his silk. On this raft he sails out to catch the insects that skim over the water.

There is a spider that lives in the water. She can dive. Her nest is like a ball. It shines like

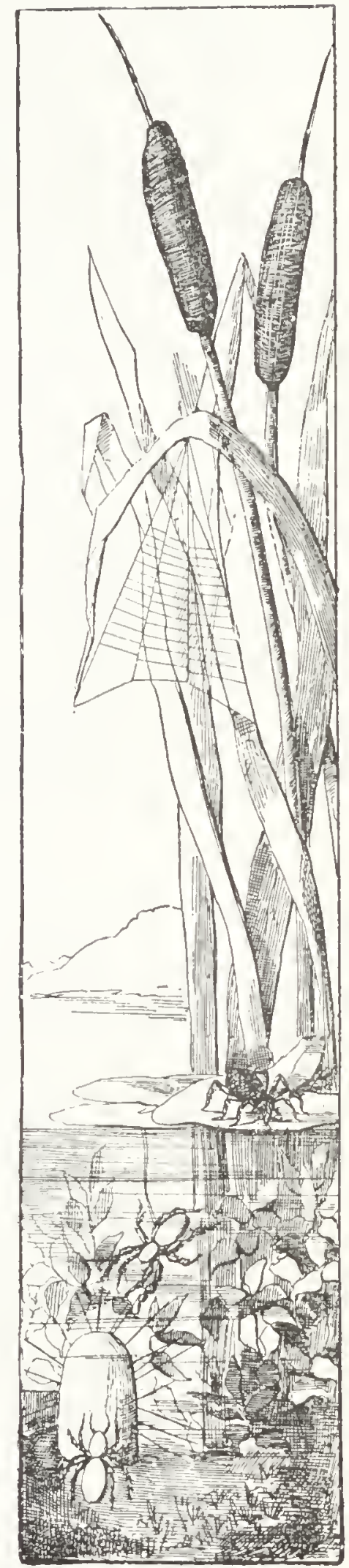

HIS DIVING-BELL. silver. Her web is so thick 
that it does not get wet. Her velvet coat keeps her as dry as a fur coat. Her eggs are of the colour of gold.

When spiders eat, they do not chew their food: they suck out the juice.

Spiders are very neat. They hate dust and soot. They will not have a dirty web. If you put a bit of dirt or leaf on the web, Mrs. Spider will go and clean it off.

She shakes her web with her foot until all the lines are clean. If the dirt will not shake from the web, the spider will cut the piece out, and inend the web with new lines.

\section{LESSON XXXI. \\ VERY QUEER SPIDERS.}

I II VEe told you of the spider that dives. I also told you of the spider that makes a raft. The one that makes the round web is the garden spider. There is a spider that rums on water. How can she do that? Have you seen boys dash about on ice with skates on their feet? Did you ever see a man walk on snow-shoes? This spider wears shoes. They are shoes made for walking on the water. 
What are they like? They are like bags of air.

It is as if she had a wee toy-balloon on each of her eight feet. She cannot sink.

There is one spider called a trap-door spider. She lives in the ground. She digs a tube down, and makes her nest deep in the earth.

Then she makes a door. It is a nice door at the top of the hole. It has a hinge. It will open and shut. It is like the lid of a box. How does she make this? She spins a thick, round web. She fills it with earth.

Then she folds the web over, to hold the dirt in. She makes a hinge of web. This trap-door will open and shut. It is firm and strong.

But the odd thing is, that the spider plants moss or small ferns on this door! She digs the moss up, sets it on her door, and it grows well. These trap-door spiders eat ants and worms. When they come out of their holes, they leave the door wide open so that they can go back.

Once a man put a lady-bird at a spider's trap-rloor. She took it in to eat. She found it had too hard a shell to bite. Then she took it back and laid it out by her door.

Then the man put a soft grub by the door, and the spider took that to eat. She did not bring that back. She ate it. 
Spiders now and then eat other spiders, but not always. One kind of spider makes a tent of leaves. She ties the leaves down with silk. Then she lives in the tent and keeps her eggs there.

One garden spider makes a nest in the shape of a pear. One ties a little ball to stems of grass.

The young spiders have not their thick coats at first. Small spiders will stay by their mother and sit on her back. They act like the small chicks with the hen. Most spiders live only one year. Some live two. Gome live over four.

There are some mason spiders. When a man is a mason, what does he do? In what does he work? There are mason wasps, and mason bees, and mason worms. Mason spiders make a nest of clay.

They take the clay in small bits and build a clay mug. It is six inches long. They line it with thick silk. The door is like a box lid. It has a hinge.

Some spiders are so small you can hardly see them. One of the very wee ones is clear, bright red. Some are very big.

The big ones are black, with spots and stripes, and have thick coats like fur. If you could find a tower spider, or a trap-door spider, and sit down to watch it build or catch its food, I think you would be happy for a whole day, or for many days. 
The tower spider builds over her hole a neat tower two or three inches high; she sits on her bower. She has as many as fifty baby spiders at once. They sit on her back for four or five weeks, until they moult two or three times. They do not fight with each other. When Mrs. Spider gets an insect for the little ones to eat, she crushes it, and the baby spiders come and suck the juice, as she holds the food for them.

\section{$-\infty .0500$ \\ LESSON XXXII. \\ REVIEW.}

What is an insect?

Name some kinds of insects.

Can you tell me how an insect's body is made?

How many legs, wings, and eyes do insects have?

What three kinds of bees live in each hive?

Tell me what the queen bee does.

What does a drone bee do, and how does he look?

Which bee makes cells?

How do bees get honey and wax?

Tell me how nurse bees take care of bee babies.

How can nurse bees make a new queen bee?

Why do the queen bees fight? 
Tell me about the fight of the queen bees.

Why does a swarm of bees leave the hive?

What do bees eat?

What do they make?

Tell me of odd places where bees live.

What things eat the bees and steal their combs?

How must you take care of bees, if you have them?

What colours do bees like best?

Tell me about ground bees.

Tell me about mason bees.

Do all bees make combs with cells that have six sides?

Is a spider an insect?

In what is he not like other insects?

What can a spider make?

How does the spider spin a web?

Tell me about the spider's eyes.

How does a spider tend its young ones?

Tell me about the water spiders.

What can you tell about other queer spiders?

What does a spider eat?

What good things can you say for the spider? 


\section{LESSON XXXIII. \\ OUT OF HARM'S WAY.}

Br this time I am sure you think that all the bees, flies, spiders, and crabs will soon be killed.

You have found how cold kills them. You have heard how they kill each other. You know that men and birds and beasts kill tlem.

How can any live? What is there to save the poor things?

The two chief things that save them are their shape and their colour.

Why, how is that?

Let us see how this is done.

On the sand by the sea the crab that lives mostly out in the air is of a gray colour. It has fine red spots like sand. The shell of this crab looks so like sand that, if he lies flat and still, you can scarcely sce him.

The crab that lives on the sea-side mud is black-green like the mud. Birds cannot see him very well, he is so like the mud that he lies on.

The spiders that live in the woods are of much the colour of a dead leaf. 
Some of them, as they lie in their webs, fold up their legs and look like a dead leaf. One spider puts a row of dead leaves and moss all along her web. She lies on this row, and looks like part of it. Birds cannot see her, as she lies in this way.

One small bee that lives in trees is green, like a new leaf. The bees, in brown, black, and gold, look like parts of the flowers on which they alight. Birds and beasts that live in snow lands, are often white, as the polar bear and the eider duck. Snakes that live on trees, or on the ground, are often brown or green. They look like the limbs of trees. Little lizards in walls are gray like stone. In woods, they often are the colour of a dead twig. These things can fold up, or stretch out, and look like twigs, or leaves, or balls of grass or hay.

All this will keep them from being seen by animals that would kill them.

Some of them you know have hard shells to shield them. Then, did I not tell you how fast they move? They dart and run and jump, quick as a flash of light. That helps them to get out of the way.

Did I not tell you, also, how the crab has his eyes set on pegs? He can turn them every way to see what is near him.

The insect and the spider do not have their eyes on 
long pegs. But do they not have six or eight eyes? These eyes are set in a bunch, and some face one way, some another. They can see all ways at once.

Then, too, so many small live things grow each year, that they cannot all be put out of the way. Each crab will lay more eggs then fifty hens. One spider has more baby spiders than you can count. One bee has more new bees in the hive each year than there are people in a large city. In a wasp's big nest there are, no doubt, as many wasps as there are leaves on a great tree.

Of the creatures which it is most easy to kill, very many are made. And so, while many of them perish each day, many are left to live.

\section{$-\infty: 0,00-\infty$ \\ LESSON XXXIV. \\ SHELL-FISH.}

HAVE you not all heard the song, "Rock-a-by Baby upon the Tree-top"? What babies live in treetops? You will say, "Bird, wasp, bee, and spider babies swing in the trees."

But do you know that there are small cradles that rock all day long on the waves? 
Up and down, in the sun, on the water, rock the cradles of many shell-fish.

What are shell-fish?

They are soft animals that live in hard shells.

But you must know that these are not true fish. True fish are animals that live in the water, and have a back-bone. The back-bone of a fish is very much like your back-bone.

All fish can swim. Most of them have fins and scales. Very many of them have long, slim, smooth bodies, that will glide easily through the water.

All of you can see fish, in the ponds, lakes, or brooks near your home. You often have them to eat on your table.

If you live in the city, you can go to the place where they sell fish and look at them.

In some other book I may tell you a little about the true fishes.

In this book I shall now tell you a very little about what are called "shell-fish."

This is not a very good name for them, but we will use it, because you will hear it from many people, and will often see it used in books.

The right name for these shell-fish is a hard word, which means "soft body" or "soft thing." That suits them very well, for they are all soft bodies; they have no bones. 
There are in the water soft--bodied things that have no shells to cover them. In the next book we will tell you of some of them.

These soft things that live in shells are mostly of a round or a wedge shape. Their shells serve them for houses to live in, for ships to sail in, for coats to cover them, for bones to keep their soft bodies in shape.

The shells of these soft things are of many forms.

Some are all in one piece, like a twist or curl. Some have two parts, like the covers of a book. These two parts are held by a hinge. And some shells are made in many pieces or scales.

There are three kinds, or orders, of shell-fish. First, the kind that has a head on its foot. Then the kind that has a head, as the snail has. Then the kind, or order, that has no head.

Well! That is a queer thing, to have no head!

Let us learn first about the shell-fish with a head and a foot.

There are many kinds of shell-fish of this order. They differ in size, colour, shape, and way of life. But if we learn about one, we shall have an idea of all. You know that the hermit crab steals a shell to live in. It is often a long shell, like a curl. That is the sort of shell that shell-fish with heads live in. It is a shell all in one piece. 
These shells are very hard and thick. Why is that? The fish in them is soft. It has no bones.

If these soft things had no hard shells, they could not live. The waves would kill them. The crabs, fish, and other animals in the sea, would eat them at once.

Let us see how a shell-fish is made. The conch, or winkle, is the largest shell-fish you will be likely

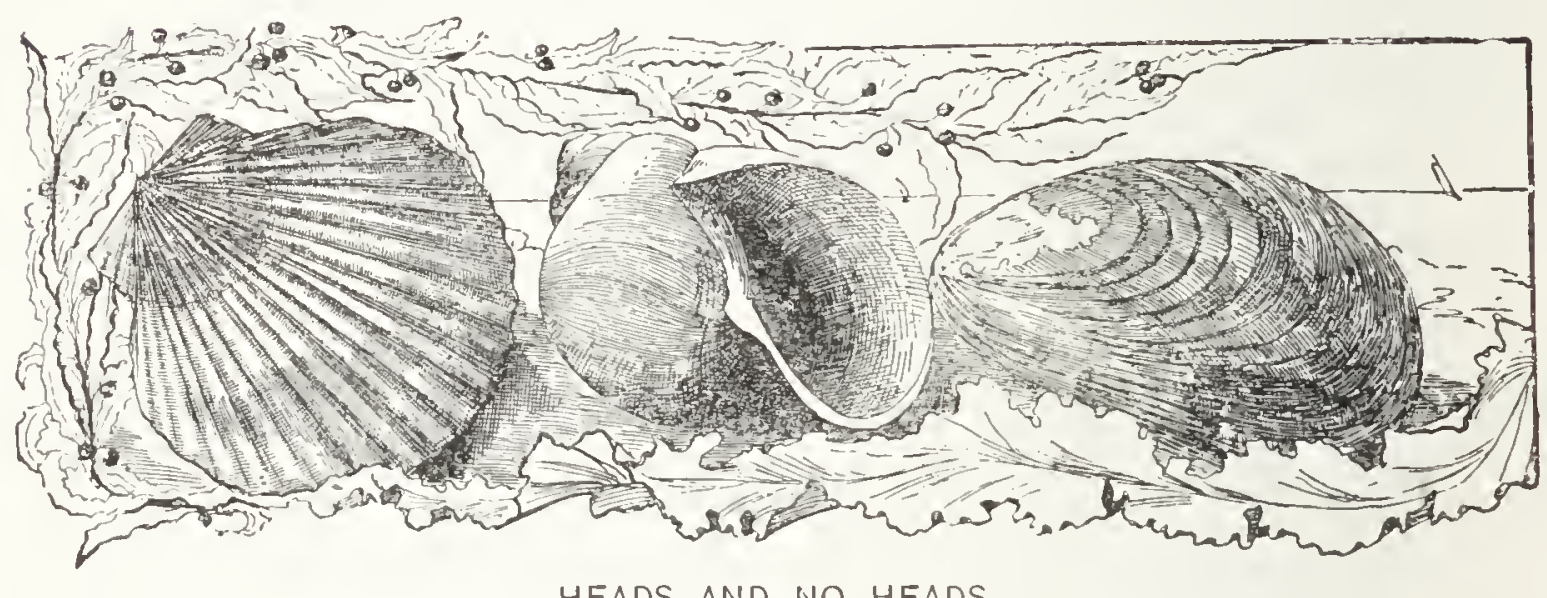

HEADS AND NO HEADS.

to find. His body is soft but tough. It runs to a point.

That back part takes fast hold of the post in the shell, so that Mr. Conch will not drop out. On one side of his body he has a hook like a thumb. That is to pull him back into his shell when he wishes to hide.

The front end of the conch is wide and thick. Here we find his mouth. Near his mouth he has two feelers, such as insects have, to touch things. 
Where the feelers join his head he has two eyes.

His foot is flat, and is as big as all the rest of his body. It is just the size of the open part of his shell. Why is that?

The shoe on his foot is hard, like horn. When he draws back into his shell, that shoe is his door. It fits close. It shuts him in safe in his shell.

\section{$-\infty ; 0500-$ \\ IESSON XXXV. \\ THE STORY OF MR. CONCH.}

THe conch or winkle does not like to live in sand, or on hard rock. He likes deep water, where he has some sand and some rock. When the wind blows, and the sea is very rough, he digs his stont foot into the sand near a stone, and holds fast, Then he does not drift on shore.

If he is cast on the shore, he will die. Mr. Conch cannot live out of water.

Mrs. Conch likes some soft sand for a bed for her babes in their queer cradles.

What does Mr. Conch eat?

He eats other shell-fish. He likes to eat oysters. How does he get them? 
He goes off to the oyster beds.

He likes the nice young oysters. He picks one up with his foot. You see he uses his foot for a hand as well as for a door. He can spread his foot out very wide. It is very, very strong.

When he has the oyster in his grip, he draws his foot close, as you would shut your hand tight. That

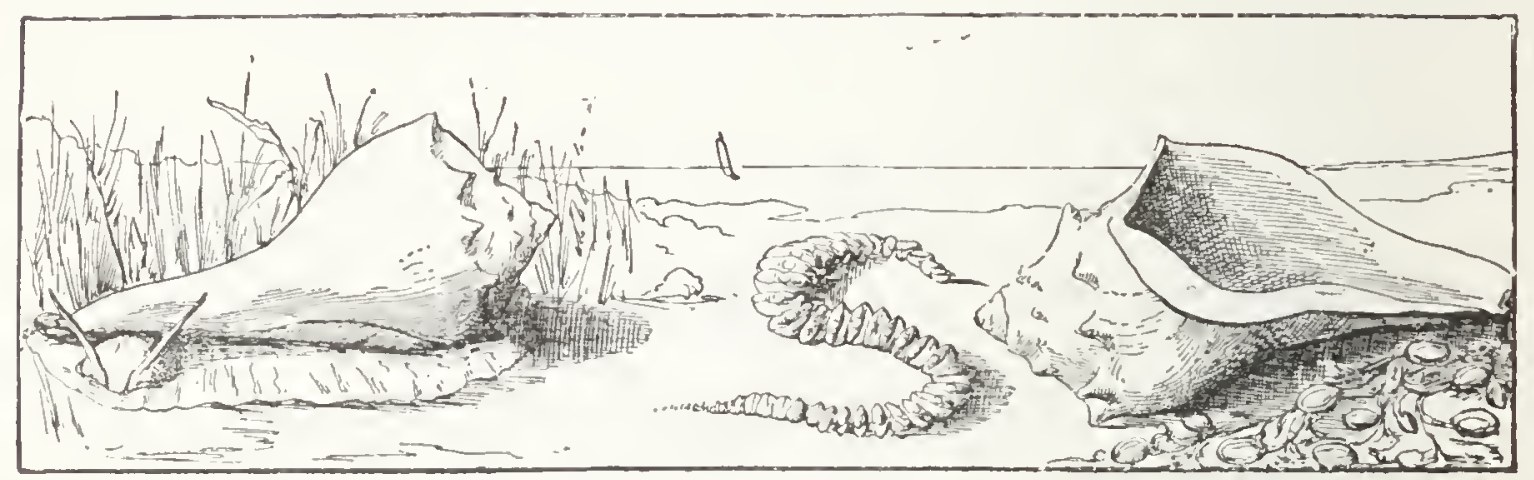

CAST AWAY ON AN ISLAND.

breaks up the shell of the oyster. Then Mr. Conch sucks up the oyster at his ease.

The men who own oyster beds do not like him, for he eats many oysters.

Mr. Conch lives a great many years. No one can hurt him in his hard house, and he has all he wants to eat.

His shell is the shape of a large pear. It has a little point at the top, and a long end like a stem. The stem end has a groore in it. His shell has a turn or twist in it, three or four times round. It is of a sand-colour, or pale yellow, outside. 
Now and then it has dark stripes on it. Inside, the shell is very smooth, and shines, and is of a fine, bright red, or pink, or yellow. It is a very pretty shell.

How does the conch grow? The conch grows from an egg. Most fish lay eggs. The eggs of the conch are in a string. They are left lying on the sand to grow.

What is the conch good for? In some places people like them to eat. Fish and crabs eat the conchs' eggs and the young conchs. The shells are made into buttons and breast-pins.

The Indians used to make money from the pink part of these shells. They also used the purple part of the round clam shell for money.

\section{LESSON XXXVI.}

\section{SEA-BABIES.}

Now we must learn more about that string of eggs that Mrs. Conch left on the sand. First it was like a thread with knots tied close together on it. Then it grew to be a yard long. It grew very fast.

The knots grew into little cases, or pockets. 'They were set close to each other. At the two ends of the string the cases were small, but after three or 
four small ones, the others were of the size and shape of big beans.

Once I was out on the sand with a boy.

We found a string of this kind. It had been cast up by the waves. It was of a pale straw-colour, and like a long curl.

The boy said, "It is a sea-weed."

I said, "No." Then he said, "It is some kind of a

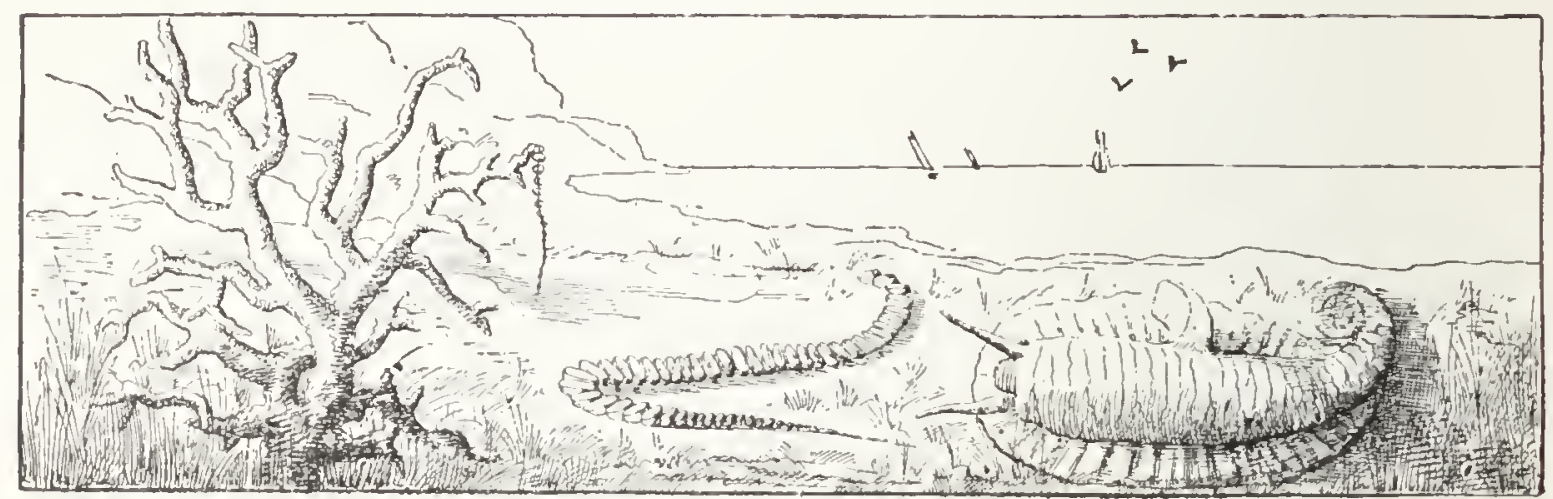

OUT IN THE COLD.

bean or seed. I said, "It is fish seed." Let us look at it.

Each case, or pocket, is flat, and has a rim. The rim has lines in it. In the front edge is a small, round spot, where the case is very thin. This is the door of the case.

The sides of the case are very tough. Let us cut one case open. It is full of white gum, or jelly.

I see in it specks like grains of sand. Here is one more string, far up on the sand. This one is dry, hard, and light. The little thin places are real holes now. 
The cases are quite empty. Here is one more string. This, too, is light and dry. But the holes in front are not open.

Shake it. Does it rattle? Yes. Cut a case open. Why! Each case is full of wee shells! Each shell is as small as a grain of rice! See how thin and white these shells are.

\section{LESSON XXXVIT. \\ MORE ABOUT SEA-BABIES.}

Now in these strings you have the whole story. First, the tiny string Mrs. Conch left on the sand grew to be a big string with large cases like these. The small specks in it were to become shells, and the jelly was to be the food of the baby conchs while in the case. There are very many in each case.

They grew and grew. They ate up all the jelly. They were true shell-fish, only very small. Now they must get out.

They saw the thin skin over the small, round hole. They felt sure that this was their door. They ate off the thin skin, and went into the sea.

The conch lays its egg-strings from March to May.

It lays a great many. In the egg-case the baby shells rock up and down, not on a tree, but on the sea. 
This dry string, still full of shells, is one in which the shells are all dead. It was cast on shore when the little fish were too young to come out. That made them all die.

These little things have a hard time to grow up. But if they can live until they are of a good size, they will have a thick shell. Then they will be out of harm's way, and will live a long time.

But how do these shell-fish grow? Do they pull off their shells when they are too tight, as crabs do?

No. All these shell-fish wear a cloak, or veil. It is by their cloak they grow. Why, how is that? This cloak, or veil, is fine and thin. It is part of the body of the fish, and folds all over it.

This fine cloak takes lime out of sea-water, and with it builds more shell. As the animal needs more room, it spreads out this veil over the edge of the shell, and builds with it new shell. You can see the little rims where the cloak built each new piece. The colour and the waved lines on the shell are made by this veil.

So the shell-fish need not change his house. He just builds on more room as he wants it. 


\section{LESSON XXXVIII. \\ ABOUT MR. DRILL.}

Here is a small shell-fish. He looks like Mr. Conch, but is not so large. He is quite small. His real size in the sea is not much larger than he is in this picture. His name is Mr. Drill.

His colour is dark brown. His shell has ridges on it.

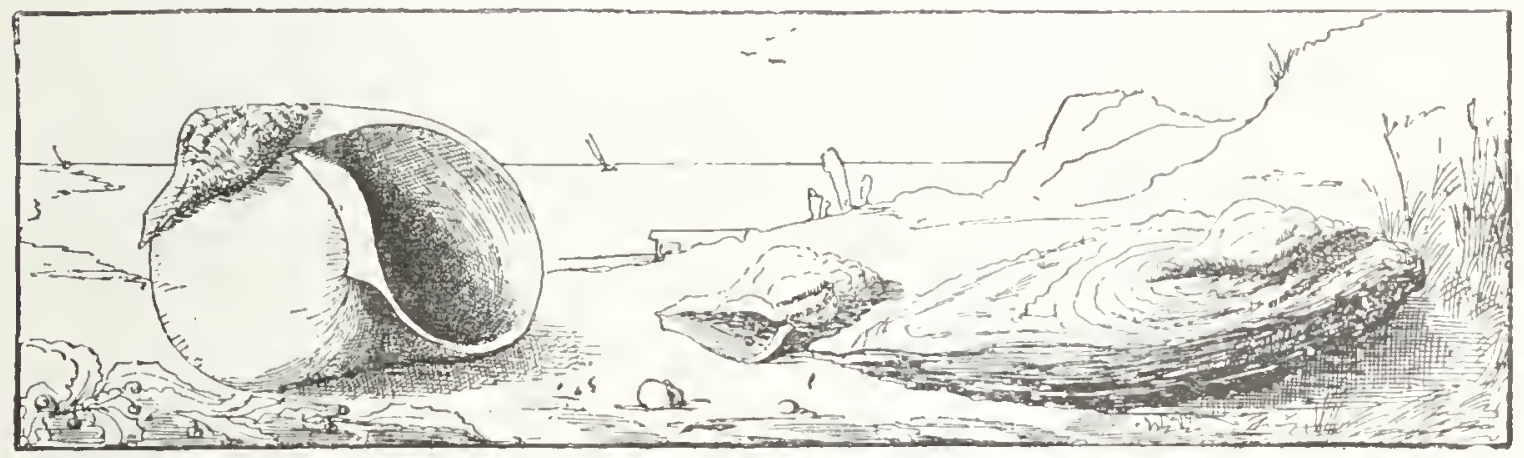

THE LITTLE ROBBER.

The body of the drill is dark green. It has a long tail to twist round in its shell.

The drill does not live alone in a place by himself. A whole host of them live near each other.

The very strangest thing about the drill is his tongue. It is from his tongue that he gets his name.

Did you ever see a man use a file? With it he can cut a hole in a piece of iron or stone. The tongue of the drill is like a file. How is this tongue made? 
It is a little soft band that will move in any way, or roll up, or push out. In this fine band are set three rows of teeth. There are many teeth in each row. The teeth are fine and as hard as the point of a pin. We could not see them if we did not use the glass that you were told of.

With this fine tongue the drill can cut or saw a hole in a thick shell.

The drill is very greedy. He eats many kinds of shellfish. He likes best of all to eat the oyster.

How does he go to work? He camnot break the shell of the oyster as the conch can. No. The way he does is this.

With his tough foot he gets fast hold of the oystershell. He picks out the thin, smooth spot called the eye of the shell. Then he goes to work to file his hole. It will take him a long time. Some say it will take him two days. But he is not lazy. He keeps fast hold and saws away. At last the hole is made clear through the shell.

It is small, smooth, even; no man could make a neater hole. Then he puts into the hole a long tube which is on the end of his cloak or veil. He can suck with that, and he sucks up the oyster till the poor thing is all gone. 


\section{LESSON XXXIX.}

THE STORY OF A WAR.

Wues the drill gets on the back of an oyster, what can the oyster do? Nothing. The poor oyster cannot help himself. Does he hear hour after hour the file of the drill on his shell? Yes.

Does he know the drill will get in and kill him? But all that he can do is to keep still and wait.

The oyster is not the only kind of shell-fish that the drill eats. When the drill goes after the poor shell-fish that have no heads, he eats them at his ease.

They cannot help themselves. They do not know how to get away from Mr. Drill. The shell-fish that have no heads live in a shell made of two parts, like the covers of a book. The two parts are held to each other by a hinge.

It is a bad thing, it seems, to have no head. Without a head who can take care of himself?

But let us see Mr. Drill try a fight with a shell-fish that has a head. Now he meets his match! He goes to the top of the shell. He makes fast, and 
begins - file, file, file. The fish inside hears him. "O, are you there, Mr. Drill?"

Then what does the shell-fish do? Why, he draws his body out of the way, and builds up a nice little wall! Then, when Mr. Drill gets his hole made, and puts in his tongue - no fish, only a hard wall! Then Mr. Drill also moves along.

He picks out a good place. Once more he goes to work - file, file, file. "O, here you are, Mr.

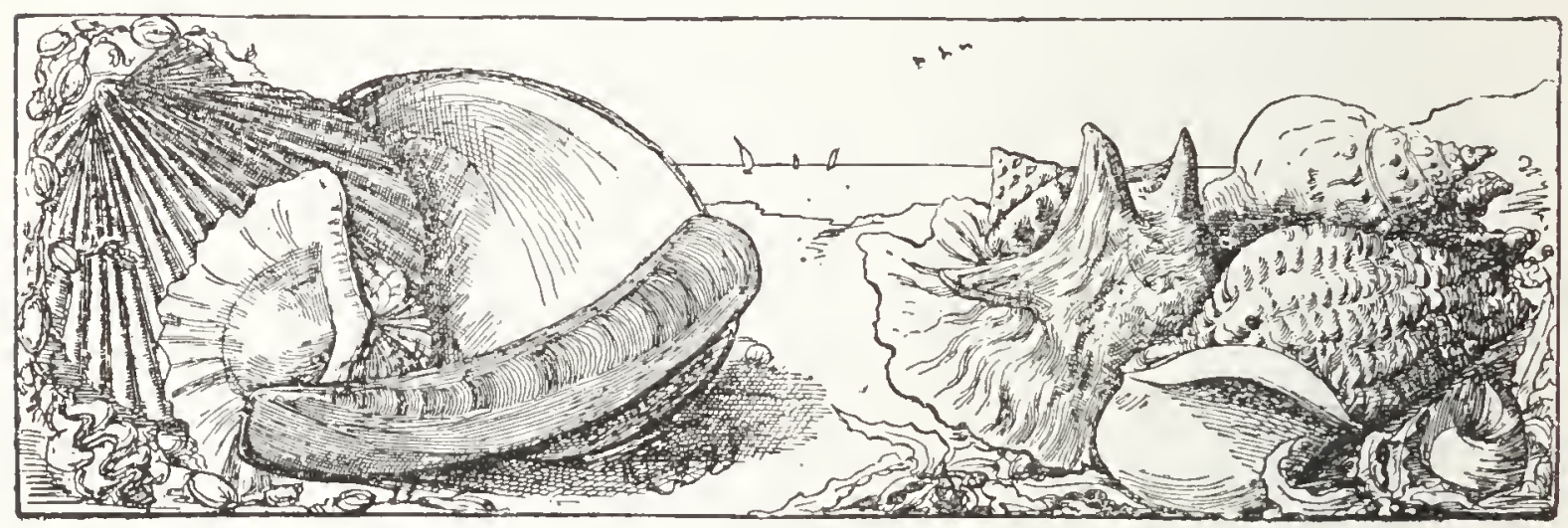

SEA-SIDE COTTAGES.

Drill!" And the shell-fish with a head once more pulls his body out of the way, and makes a new wall.

Then Mr. Drill has the same luck as before. Sometimes he grets tired of the war and goes off. Now and then, as he too has a head, he finds a spot where there is no room for the wall. Then he makes his hole and sucks out the animal.

You will find very many of the shells on the sea-beach 
with these pin-holes in them. The holes were made by Mr. Drill on his hunt for food.

But you will now and then find shells, as the thick clam shell, full of holes, like a network. This is not done by Mr. Drill.

Shells and bones are made of two kinds of stuff. One is lime, which is hard like stone. The other is not so hard; it is more like dry glue.

These shells with so many holes are old shells, long. dead, and the glue part has gone out. of them.

How did it get out? It was bored out by a kind of sponge. Only the lime part is left, like a fine net. When bones or shell have only the lime part left, they will break and crack like glass. If they have too little lime, they will bend.

For all Mr. Drill has a head, he is not so wise as at first he seemed to be.

He will sit down and make a hole in an old dead shell where no fish lives. Now and then he makes a hole in an old shell, long ago turned into stone. He will spend two days on such a shell as this!

Did you know that bones and shells and plants sometimes turn to stone?

You will some day learn about that strange fact. 


\section{$\rightarrow \rightarrow \infty$ \\ LESSON XL. \\ HOW SHELL-FISH FEED.}

Do the shell-fish all feed on other shell-fish? Oh, no. Some of them live on sea-weed. Some of them live by fishing. They catch, from the water, small bits of food, as small as grains of sand.

The shell-fish that live on sea-weed have a long, slim tongue. It is somewhat like that of the drill. The tongue is like a tiny strap.

The teeth are set on it, three or more in a row, like the points of pins. As the teeth wear out from work on the tough weed, more grow.

These shell-fish walk along on their one big foot. First one side of the foot spreads out, and then the other.

That pulls them along. Is it not very slow work? But what of that? All they have to do is to move about and find food.

They can take all day for it. They have no house to build and no clothes to make.

They creep along to a good bed of sea-weed. Then they put out the fine, file-like tongue. 
It cuts off flakes of sea-weed for them to eat. They are never tired of that one kind of food.

Even that queer limpet, who sits on a rock and has a shell like a cap, has a head, and a foot, and a tongue that is like a rasp. And he can walk along the floor of the sea.

He can climb up the rocks. The limpet has his own rock and his own hole in the rock. He goes back

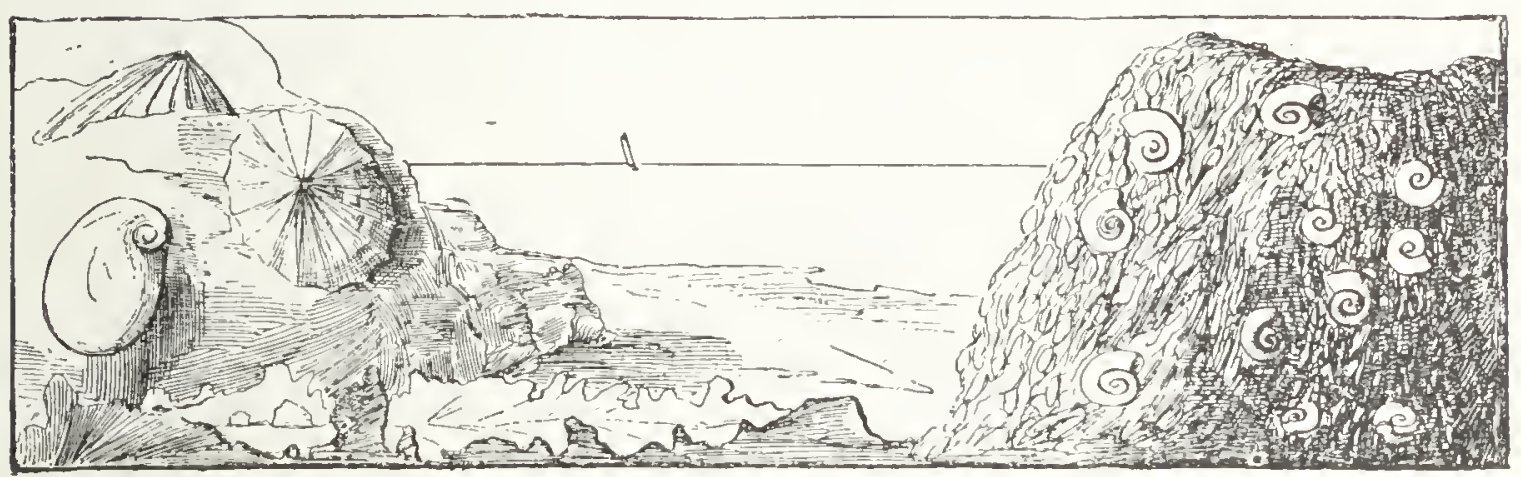

AT LOW TIDE.

to his rock when he has had all that he wants to eat.

The world of the sea is as full of life as the world of the land. There is one nice little shell-fish, about as big as a pea. He lives in the sea-weed that grows on rocks. He is brown, or green, or black, or red, or dark yellow.

He can live in the damp weed in the hours when the tide is out, and has left the rocks dry. He eats sea-weed. Let us look at him. He has two little feelers. 
He has two wee, black eyes. He has a little snout, like a tiny pig. At the end of this snout is his little mouth. His small, dark foot has a dent in it.

He puts out his wee, file-like tongue, and laps it out and in, as a dog does when he drinks water. The sharp teeth cut off little scales of weed for him to eat. Take ten or more of these little shells in your hand. Each tiny animal draws in his wee foot. As the little animals hide in this way, put down your ear, and you will hear a small squeak.

\section{$\longrightarrow \infty+\infty$ \\ LESSON XLI. \\ REVIEW.}

WIIAT is a shell-fish?

What three great orders of shell-fish are there?

Did you say there are many kinds?

Name some of the kinds.

What kind of shell do the fish with a head and a foot live in?

Tell me how these shell-fish grow.

Tell me about the conch cradles.

Where do these fish like to live?

Why do they need to wear these hard shells?

Do they change their shells? 
How, then, do they grow?

Why are not more blown ashore?

Tell me what they eat.

How do they kill and eat other shell-fish?

Do all fish lay eggrs?

How do shell-fish eat sea-weed?

What are shell-fish good for?

What shell-fish is most eaten?

What did the Indians make out of the shells?

Tell me about the veil, or cloak, of the shell-fish. Tell me more about the foot.

Tell me how Mr. Drill makes war.

Of what are shells and bones made?

How is Mr. Drill's tongue made?

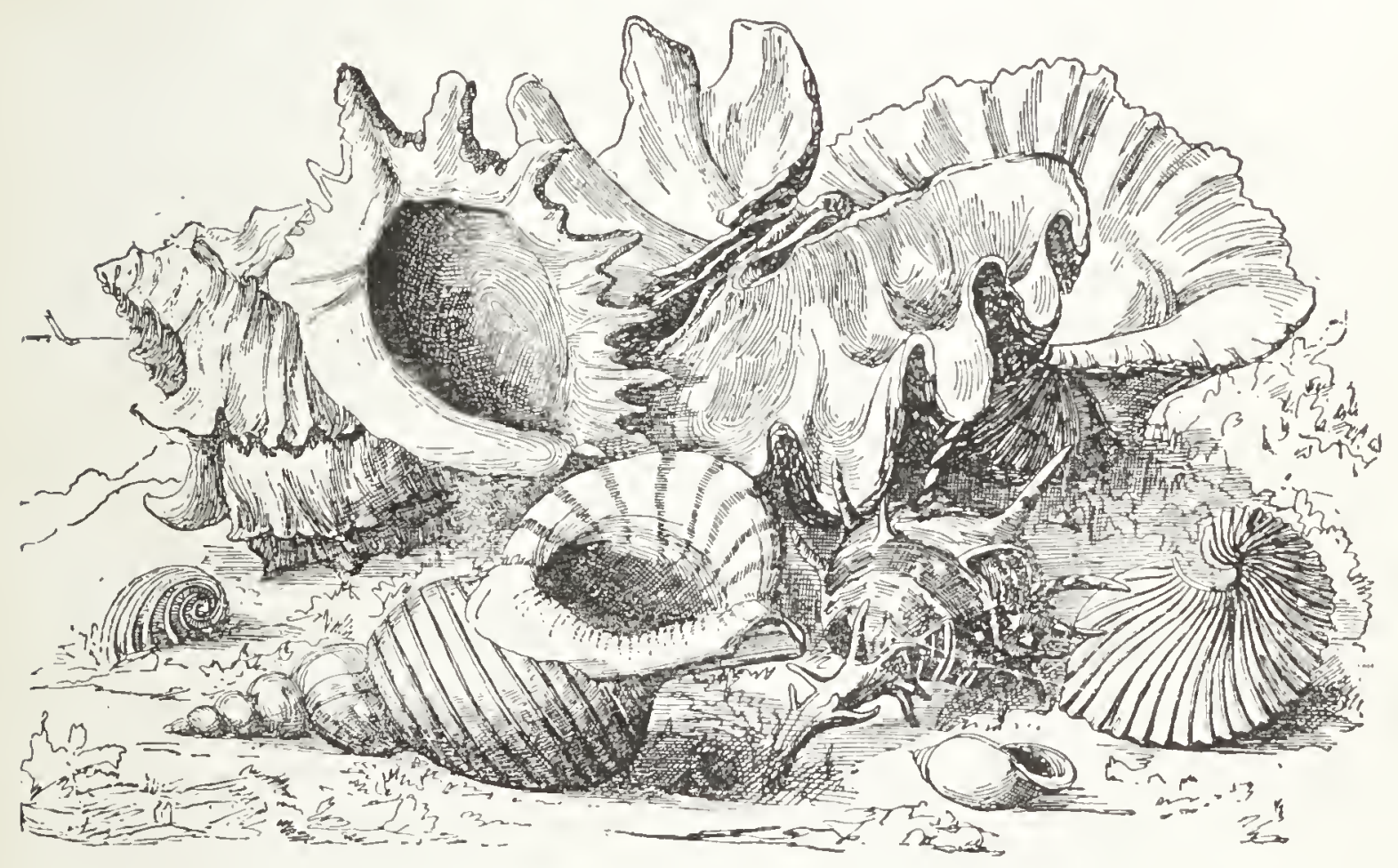




,

3

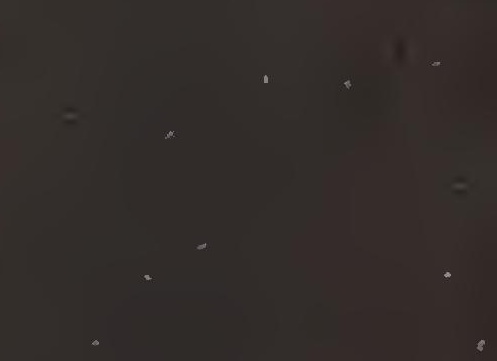





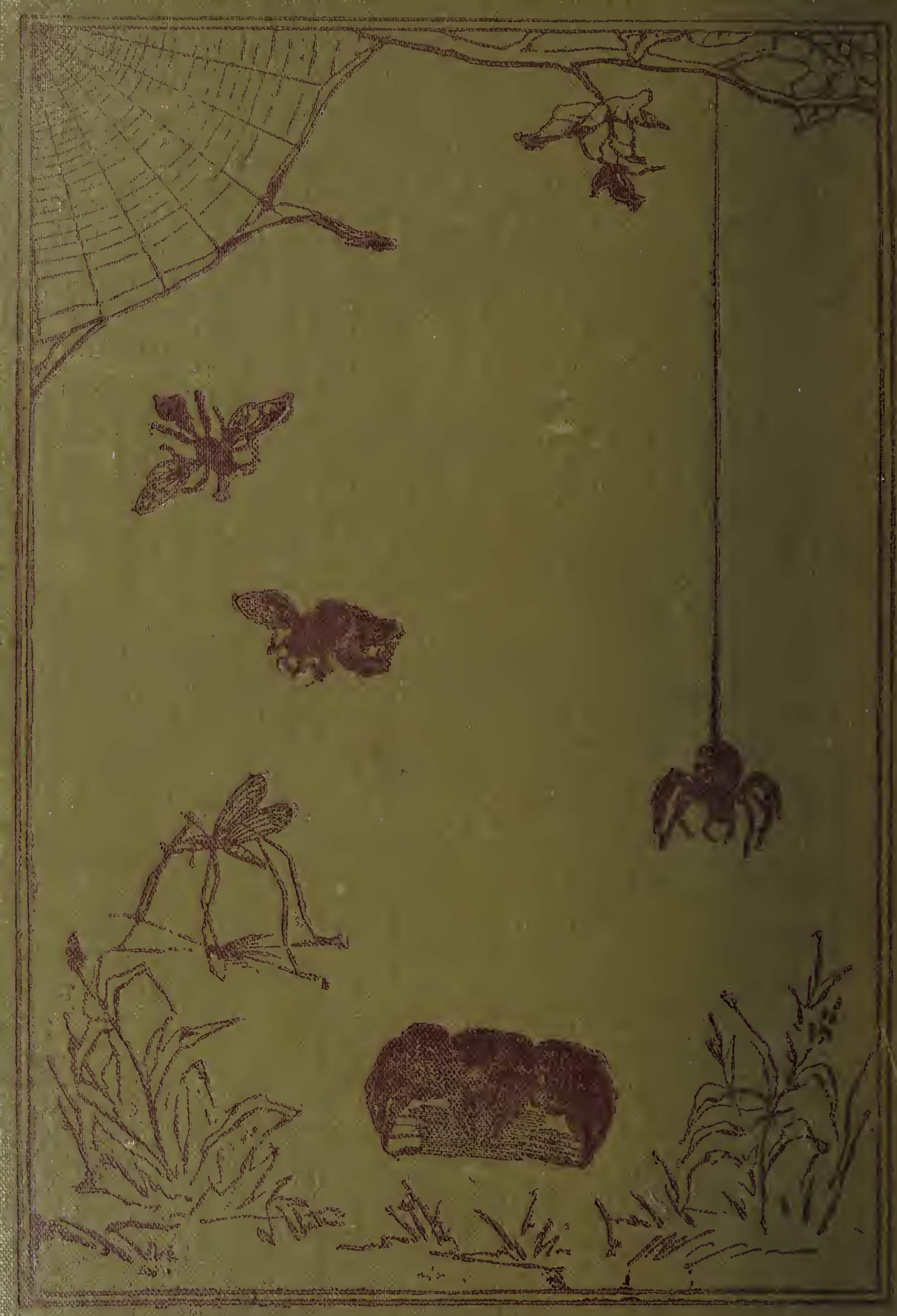

